\title{
Does GOSAT capture the true seasonal cycle of carbon dioxide?
}

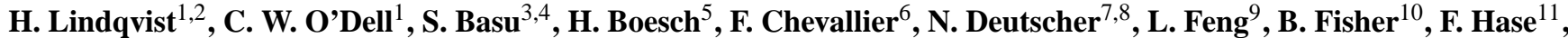 \\ M. Inoue ${ }^{12,13}$, R. Kivi ${ }^{14}$, I. Morino ${ }^{12}$, P. I. Palmer ${ }^{9}$, R. Parker ${ }^{5}$, M. Schneider ${ }^{11}$, R. Sussmann ${ }^{15}$, and Y. Yoshida ${ }^{12}$ \\ ${ }^{1}$ Department of Atmospheric Science, Colorado State University, CO, USA \\ ${ }^{2}$ Finnish Meteorological Institute, Helsinki, Finland \\ ${ }^{3}$ NOAA Earth System Research Laboratory, Boulder, CO, USA \\ ${ }^{4}$ Cooperative Institute for Research in Environmental Sciences, University of Colorado, Boulder, CO, USA \\ ${ }^{5}$ National Centre for Earth Observation, Department of Physics and Astronomy, University of Leicester, Leicester, UK \\ ${ }^{6}$ Laboratoire des Sciences du Climat et de l'Environnement, CEA-CNRS-UVSQ, Gif-sur-Yvette, France \\ ${ }^{7}$ School of Chemistry, University of Wollongong, Wollongong, Australia \\ ${ }^{8}$ Institute of Environmental Physics, University of Bremen, Bremen, Germany \\ ${ }^{9}$ National Centre for Earth Observation, School of GeoSciences, University of Edinburgh, Edinburgh, UK \\ ${ }^{10}$ Jet Propulsion Laboratory, California Institute of Technology, Pasadena, CA, USA \\ ${ }^{11}$ Karlsruhe Institute of Technology, IMK-ASF, Karlsruhe, Germany \\ ${ }^{12}$ National Institute for Environmental Studies (NIES), Tsukuba, Japan \\ ${ }^{13}$ Department of Biological Environment, Akita Prefectural University, Akita, Japan \\ ${ }^{14}$ Finnish Meteorological Institute, Arctic Research Centre, Sodankylä, Finland \\ ${ }^{15}$ Karlsruhe Institute of Technology, IMK-IFU, Garmisch-Partenkirchen, Germany
}

Correspondence to: H. Lindqvist (hannakaisa.lindqvist@fmi.fi)

Received: 17 April 2015 - Published in Atmos. Chem. Phys. Discuss.: 17 June 2015

Revised: 9 November 2015 - Accepted: 10 November 2015 - Published: 24 November 2015

\begin{abstract}
The seasonal cycle accounts for a dominant mode of total column $\mathrm{CO}_{2}\left(\mathrm{XCO}_{2}\right)$ annual variability and is connected to $\mathrm{CO}_{2}$ uptake and release; it thus represents an important quantity to test the accuracy of the measurements from space. We quantitatively evaluate the $\mathrm{XCO}_{2}$ seasonal cycle of the Greenhouse Gases Observing Satellite (GOSAT) observations from the Atmospheric $\mathrm{CO}_{2}$ Observations from Space (ACOS) retrieval system and compare average regional seasonal cycle features to those directly measured by the Total Carbon Column Observing Network (TCCON). We analyse the mean seasonal cycle amplitude, dates of maximum and minimum $\mathrm{XCO}_{2}$, as well as the regional growth rates in $\mathrm{XCO}_{2}$ through the fitted trend over several years. We find that GOSAT/ACOS captures the seasonal cycle amplitude within $1.0 \mathrm{ppm}$ accuracy compared to TCCON, except in Europe, where the difference exceeds $1.0 \mathrm{ppm}$ at two sites, and the amplitude captured by GOSAT/ACOS is generally shallower compared to TCCON. This bias over Europe is not as large for the other GOSAT retrieval algorithms (NIES v02.21, RemoTeC v2.35, UoL v5.1, and NIES PPDF-S v.02.11), al-
\end{abstract}

though they have significant biases at other sites. We find that the ACOS bias correction partially explains the shallow amplitude over Europe. The impact of the co-location method and aerosol changes in the ACOS algorithm were also tested and found to be few tenths of a ppm and mostly non-systematic. We find generally good agreement in the date of minimum $\mathrm{XCO}_{2}$ between ACOS and TCCON, but ACOS generally infers a date of maximum $\mathrm{XCO}_{2} 2-3$ weeks later than TCCON. We further analyse the latitudinal dependence of the seasonal cycle amplitude throughout the Northern Hemisphere and compare the dependence to that predicted by current optimized models that assimilate in situ measurements of $\mathrm{CO}_{2}$. In the zonal averages, models are consistent with the GOSAT amplitude to within $1.4 \mathrm{ppm}$, depending on the model and latitude. We also show that the seasonal cycle of $\mathrm{XCO}_{2}$ depends on longitude especially at the mid-latitudes: the amplitude of GOSAT $\mathrm{XCO}_{2}$ doubles from western USA to East Asia at $45-50^{\circ} \mathrm{N}$, which is only partially shown by the models. In general, we find that model-tomodel differences can be larger than GOSAT-to-model dif- 
ferences. These results suggest that GOSAT/ACOS retrievals of the $\mathrm{XCO}_{2}$ seasonal cycle may be sufficiently accurate to evaluate land surface models in regions with significant discrepancies between the models.

\section{Introduction}

Space-based observations of column mean dry mole fraction of carbon dioxide $\left(\mathrm{XCO}_{2}\right)$ provide unprecedented spatial coverage of the variability of atmospheric carbon dioxide. $\mathrm{XCO}_{2}$ shows temporal variability on different timescales: diurnal, synoptic, seasonal, interannual, and long term (Olsen and Randerson, 2004; Keppel-Aleks et al., 2011). Variability is determined by the collective impact of $\mathrm{CO}_{2}$ fluxes resulting from fossil fuel emissions, biosphere-atmosphere exchange, and ocean-atmosphere exchange. In addition, significant variability is driven by atmospheric dynamics acting upon the gradients produced by the varying fluxes. While the secular trend and multi-year interhemispheric $\mathrm{CO}_{2}$ gradient are driven by the global build-up of $\mathrm{CO}_{2}$ from fossil fuel combustion mainly in the Northern Hemisphere, the seasonal variability is mainly controlled by variations in the terrestrial biospheric fluxes (Palmer et al., 2008; Keppel-Aleks et al., 2011). The seasonally varying ocean-atmosphere and fossil fuel $\mathrm{CO}_{2}$ fluxes are only minor contributors to the $\mathrm{XCO}_{2}$ seasonal variability in the Northern Hemisphere. Therefore, the seasonal cycle of $\mathrm{XCO}_{2}$ bears the signature of large-scale biospheric flux patterns, especially their north-south distribution.

Land surface models that describe the biosphereatmosphere carbon exchange in larger modelling systems, such as coupled climate-carbon cycle models, seek to accurately represent regional-scale biospheric fluxes of $\mathrm{CO}_{2}$ (Pitman, 2003). Inverse model systems use atmospheric $\mathrm{CO}_{2}$ observations together with atmospheric transport models to improve upon the $\mathrm{CO}_{2}$ flux estimates of the land surface models. In regions where the in situ measurement network has sparse coverage, the inverse models often strongly disagree about the seasonality and magnitude of the fluxes (e.g. Gurney et al., 2002, 2003). Recently, this disagreement has been found to lead to large regional discrepancies of several ppm in the seasonal cycle amplitudes of modelled $\mathrm{XCO}_{2}$ (Keppel-Aleks et al., 2012; Peng et al., 2015; Lindqvist et al., 2015). This finding suggests that regional $\mathrm{XCO}_{2}$ seasonal cycles may be indicative of local fluxes and hence that satellitemeasured $\mathrm{XCO}_{2}$ may be useful in evaluating model fidelity without resorting to full carbon flux inversions. It is also another reminder that there may be much to be gained by assimilating space-based $\mathrm{XCO}_{2}$ retrievals which vastly expand the current in situ measurement network, a lesson shown previously by a number of studies (e.g. Rayner and O'Brien, 2001; Chevallier et al., 2007; Takagi et al., 2011; Maksuytov et al., 2013; Takagi et al., 2014). In particular, the strength of the seasonal cycle drawdown is fundamentally connected to the magnitude of the carbon sink during the growing season. By studying the Greenhouse Gases Observing Satellite (GOSAT; Yokota et al., 2009) $\mathrm{XCO}_{2}$ seasonal cycle and its interannual variability, Wunch et al. (2013) showed that the variability in the drawdown correlates with surface temperature in the boreal regions, and Guerlet et al. (2013b) found a reduced carbon uptake during the 2010 Northern Hemisphere summer.

GOSAT and the Orbiting Carbon Observatory-2 (OCO-2; Crisp et al., 2004) are designed to make near-global $\mathrm{XCO}_{2}$ measurements that will constrain the inverse model systems enough to provide a picture of the global carbon cycle with respect to regional sources and sinks. As a first step in evaluating the potential of such measurements to provide improved insight into the global carbon cycle, in this study we ask perhaps the first-order question: are the satellite observations accurate enough to reliably capture the seasonal variability of $\mathrm{XCO}_{2}$ ? The question is fair because satelliteretrieved $\mathrm{XCO}_{2}$ is subject to biases in the retrieval system (e.g. Wunch et al., 2011b) and also sampling biases due to the seasonally dependent amount of solar radiation (e.g. Liu et al., 2014). Both of these may have an impact on the measured seasonal cycle. For the Atmospheric $\mathrm{CO}_{2}$ Observations from Space (ACOS) retrieval system (O'Dell et al., 2012; Crisp et al., 2012), known biases in GOSAT retrievals are corrected using a global bias correction (Wunch et al., 2011b) but some parameters of the bias correction, for example surface albedo, vary seasonally. Potential remaining biases, their seasonality, and impact on the seasonal cycles of $\mathrm{XCO}_{2}$ are best identified through evaluation of the GOSAT seasonal cycle against the best available independent data - those from the Total Carbon Column Observing Network, TCCON (Wunch et al., 2011a). There have been several studies that compare GOSAT retrievals against the TCCON, some of them introducing novel methods for comparisons (Wunch et al., 2011b; Nguyen et al., 2014), some concentrating on quantifying biases in a specific retrieval algorithm (Butz et al., 2011; Cogan et al., 2012; Yoshida et al., 2013), and some focusing more on the intercomparison of different retrieval algorithms (Buchwitz et al., 2013; Oshchepkov et al., 2013a; Reuter et al., 2013; Dils et al., 2014). Overall, the collective message from the validation studies is that the agreement of GOSAT and TCCON has improved (i.e. the satellite biases have decreased) substantially from the earliest validation efforts (Morino et al., 2011), owing to major improvements and updates in the retrieval algorithms and the development of more sophisticated comparison methods. However, less attention has been paid to the evaluation of the seasonal cycle. Reuter et al. (2013, p. 1776) touched on this by showing averages of the seasonal cycle amplitude differences between all GOSAT retrievals and TCCON (and also a model, CarbonTracker CT2011_oi). More recently, Kulawik et al. (2015) studied the seasonality of GOSAT-TCCON biases (using the ACOS B3.4 retrieval algorithm for GOSAT data) and found not only notable station-to-station variability in the biases but 
also persisting seasonal biases in latitudinally averaged results. These seasonal biases were reflected in the seasonal cycle amplitudes.

In this paper, we continue the evaluation of the GOSAT seasonal cycle from Kulawik et al. (2015). Five years of GOSAT observations and the updated TCCON GGG2014 retrievals lengthen the co-located time series sufficiently to evaluate the seasonal cycles regionally at 12 TCCON sites in the Northern Hemisphere and four sites in the Southern Hemisphere. We extend the seasonal cycle analysis to four other retrieval algorithms to identify potential biases characteristic to the ACOS retrievals. Although the emphasis of the study is on these TCCON comparisons, we also compare the GOSAT seasonal cycle against models that assimilate in situ data; because of their connection to measurements, models may be a reasonable representation of the truth in areas with high assimilated data density, such as North America or western Europe. This seasonal cycle evaluation study lays important ground work to the analysis of OCO-2 observations that also use the ACOS retrieval system and are, therefore, likely to be affected by any seasonal biases present in the GOSAT/ACOS retrievals that are due to the ACOS system or ACOS a priori inputs.

\section{GOSAT}

GOSAT, developed by Japan Aerospace Exploration Agency (JAXA), was launched in January 2009 to make near-global greenhouse gas measurements from a polar orbit (Yokota et al., 2009). GOSAT measures reflected solar near-infrared radiation with a Fourier transform spectrometer (TANSO-FTS; Kuze et al., 2009). The diameter of a GOSAT sounding footprint is approximately $10 \mathrm{~km}$, and the soundings repeat in a 3-day cycle. We used GOSAT data taken in two primary modes: glint over oceans and nadir view over land. Nadir data over land have two gain states: high gain $(\mathrm{H})$ for most of the data and medium (M) over bright surfaces, such as deserts.

Several retrieval algorithms have been developed for retrieving the column-averaged $\mathrm{CO}_{2}$ from the GOSAT nearinfrared measurements; these algorithms have been recently reviewed and compared by Oshchepkov et al. (2013a) and Reuter et al. (2013). In this paper, we concentrate on the evaluation of the Atmospheric $\mathrm{CO}_{2}$ Observations from Space build 3.5 (ACOS B3.5) retrieval algorithm (Crisp et al., 2012). The ACOS retrieval algorithm is described in detail by O'Dell et al. (2012). The most significant subsequent updates and improvements to the operational algorithm include updated spectroscopy for the 1.6 and $2.1 \mu \mathrm{m} \mathrm{CO}_{2}$ absorption bands, moving from static to dynamic vertical pressure levels, an improved prior profile of $\mathrm{CO}_{2}$, and a complete change in the treatment of aerosol and cloud scattering. Instead of a globally constant aerosol model that was incorporated in ACOS B3.4 and earlier versions, B3.5 uses Modern-
Era Retrospective Analysis for Research and Applications (MERRA) reanalysis data of five aerosol types (mineral dust, sea salt, black carbon, sulphates, and organic carbon) to determine two most common types at a given GOSAT sounding location and applies their respective optical properties in the retrieval.

\section{Validation data}

\subsection{TCCON}

The Total Carbon Column Observing Network (TCCON) is currently composed of 21 operating Fourier transform spectrometers that make ground-based measurements of atmospheric $\mathrm{XCO}_{2}$ and other gases (Wunch et al., 2011a). These measurements provide an ideal, independent validation source for GOSAT for two reasons. Firstly, they measure the same quantity in essentially the same way as the satellites, though looking directly at the sun rather than sunlight reflected off the Earth, and so are not affected by surface albedo. Secondly, the TCCON measurements are independently validated and calibrated, and their precision and accuracy are higher than those of the satellite observations (Wunch et al., 2010; Messerschmidt et al., 2011). Though the seasonal cycle of TCCON has itself never been explicitly validated by comparison with aircraft, we implicitly assume that our inferred TCCON seasonal cycles for $\mathrm{XCO}_{2}$ can be taken as truth, similar to the assumption in several previous studies (Messerschmidt et al., 2011; Keppel-Aleks et al., 2012; Wunch et al., 2013), though in principle sub-ppm seasonal biases could remain. For instance, the TCCON retrieval performs a post hoc air-mass bias correction (Wunch et al., 2011a), errors in which could lead to small but nontrivial differences in the TCCON seasonal cycle. In fact, we tested this for Lamont TCCON station (because of its large data volume) by considering only data obtained at a similar air mass and found that the differences in the $\mathrm{XCO}_{2}$ seasonal cycle amplitude were less than $0.3 \mathrm{ppm}$ compared to the amplitude derived using the full data set.

For the GOSAT seasonal cycle evaluation, we used data from all TCCON sites that had (1) at least 2 years of coincidental measurements with GOSAT and (2) enough colocated data (see Sect. 4.1) to evaluate a seasonal cycle, i.e. both ACOS and TCCON observations available at the proximity of the site through most seasons. The first criterion eliminated the Ascension, Four Corners, and Caltech/Pasadena sites, while the second eliminated the northernmost sites of Ny Ålesund and Eureka which have very little co-located data due to the high latitude. We decided to focus our analysis on the Northern Hemisphere which has both a larger seasonal cycle amplitude and a larger quantity of TCCON stations against which to compare. The seasonal cycles at the southern hemispheric sites were also evaluated, and we found that the seasonal changes in $\mathrm{XCO}_{2}$ in the South- 
ern Hemisphere were minor with an amplitude of around $1.0 \mathrm{ppm}$ and captured by GOSAT/ACOS to within $0.2 \mathrm{ppm}$ except at Réunion where the satellite data showed a stronger seasonal cycle of $1.8 \mathrm{ppm}$. However, because the seasonal variability in $\mathrm{XCO}_{2}$ at the southern hemispheric sites is of a similar magnitude than the single-sounding errors in the GOSAT/ACOS retrievals, the definition of an average seasonal cycle becomes ambiguous and sensitive to interannual variability. Therefore, these four southern hemispheric TCCON sites were not analysed in more detail.

All TCCON sites that were used in this study are shown in Fig. 1. We analysed all co-located data between 23 April 2009 and 31 December 2013. We used the newest available GGG2014 TCCON retrievals for each site: Bialystok (Messerschmidt et al., 2012; Deutscher et al., 2014), Bremen (Notholt et al., 2014), Darwin (Griffith et al., 2014a), Garmisch (Sussmann and Rettinger, 2014), Izaña (Blumenstock et al., 2014), JPL (Wennberg et al., 2014a), Karlsruhe (Hase et al., 2014), Lamont (Wennberg et al., 2014c), Lauder (Sherlock et al., 2014), Orleans (Warneke et al., 2014), Park Falls (Washenfelder et al., 2006; Wennberg et al., 2014b), Réunion (De Maziere et al., 2014), Saga (Kawakami et al., 2014), Sodankylä (Kivi et al., 2014), Tsukuba (Ohyama et al., 2009; Morino et al., 2014), and Wollongong (Griffith et al., 2014b). TCCON data were obtained from the TCCON Data Archive website at http://tccon.ornl.gov/.

\subsection{Model $\mathrm{CO}_{2}$ data}

Because evaluation against TCCON is limited to 12 sites in the Northern Hemisphere, another validation source is necessary for obtaining a more thorough view of the accuracy of the GOSAT seasonal cycle. Therefore, we also analysed $\mathrm{XCO}_{2}$ from three models that assimilate in situ $\mathrm{CO}_{2}$ measurements to optimize their fluxes. The models were CarbonTracker (CT2013B; Peters et al., 2007, with updates documented at http://carbontracker.noaa.gov), MACC 13.1 (Chevallier et al., 2010, documentation and data available at http://macc.copernicus-atmosphere.eu/catalogue), and the University of Edinburgh model (UoE; Feng et al., 2009, 2011, http://www.palmergroup.org). Relevant model properties are listed in Table 1. The models were resampled at GOSAT/ACOS observations in latitude, longitude, and time and integrated over all atmospheric layers to form the column-averaged $\mathrm{CO}_{2}$. The ACOS averaging kernel correction was first considered for CT2013B, but as it had only a very minor effect on the total column (generally $<0.1 \mathrm{ppm}$ difference in monthly averages), it was subsequently neglected for all models. However, seasonal effects of the averaging kernel correction are briefly assessed in Sect. 5.3. All model results were available from the beginning of GOSAT data (23 April 2009) but have different end dates: UoE and CT2013B run until the end of December 2012, and MACC 13.1 is available until the end of December 2013.

\section{Methods}

In this section, we describe the co-location of ground-based and satellite remote sensing measurements, filtering and bias correction for GOSAT/ACOS, and the averaging kernel correction and define the average seasonal cycle. We demonstrate these steps with an example TCCON site at Park Falls, Wisconsin, USA.

\subsection{Co-locating GOSAT and TCCON}

ACOS retrievals of GOSAT soundings are estimates of total column $\mathrm{XCO}_{2}$. Therefore, the issue of co-locating GOSAT soundings with TCCON soundings boils down to the question of whether we expect both sounding locations to have the same atmospheric $\mathrm{XCO}_{2}$. Any co-location technique is an assumption about the geographical region over which we expect $\mathrm{XCO}_{2}$ to be the same as a TCCON retrieval, within some tolerance. For example, a geometrical co-location criterion, where we consider all GOSAT soundings within some fixed distance of a TCCON station, assumes that in the real atmosphere the variation of $\mathrm{XCO}_{2}$ over that distance is smaller than said tolerance. Similarly, co-locating using the $700 \mathrm{hPa}$ potential temperature (Wunch et al., 2011b) assumes that air with the same transport history - in so far as it is reflected in the $700 \mathrm{hPa}$ potential temperature - will have the same $\mathrm{XCO}_{2}$ (within said tolerance). However, neither of these co-location techniques account for the fact that ultimately atmospheric $\mathrm{XCO}_{2}$ is a convolution of surface fluxes and transport. Therefore, in our paper we have applied the NOAA/Basu co-location technique (Guerlet et al., 2013a) which uses a modelled atmospheric $\mathrm{XCO}_{2}$ field to delineate the region around a TCCON station over which we expect $\mathrm{XCO}_{2}$ to be constant within some tolerance $(0.5 \mathrm{ppm}$ for this work). Since the model is run with realistic surface fluxes and atmospheric transport, we expect this co-location technique to account for $\mathrm{XCO}_{2}$ variations due to both. To set upper spatiotemporal limits for the co-located soundings, the GOSAT soundings were required to be within $\pm 22.5^{\circ}$ in longitude and $\pm 7.5^{\circ}$ in latitude from the TCCON site and acquired on the same day, within $2 \mathrm{~h}$ of each other. We considered all valid TCCON soundings within $\pm 1 \mathrm{~h}$ time window around the GOSAT overpass time to exclude any effects from the diurnal cycle of $\mathrm{XCO}_{2}$. In practice, the NOAA/Basu colocation technique has several advantages: high co-location data volume, good accuracy, and good sampling of parameter space, such as surface albedo. It should also be noted that the performance of this technique does not depend on the absolute accuracy of simulated $\mathrm{XCO}_{2}$; all that is required is for the spatial gradient of 3-day average $\mathrm{XCO}_{2}$ over a few thousand kilometres to be correct to within some tolerance, in addition to the temporal $2 \mathrm{~h}$ criterion.

The NOAA/Basu co-location technique is visually demonstrated for the Park Falls TCCON site in Fig. 2a. All GOSAT soundings over almost 5 years of co-located observations at 


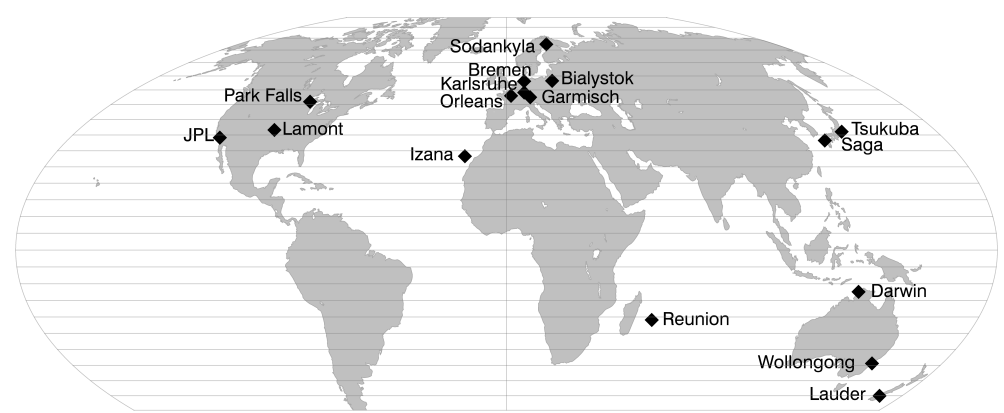

Figure 1. TCCON sites used for GOSAT evaluation in this study.

Table 1. Models used in the evaluation of the GOSAT seasonal cycle.

\begin{tabular}{llll}
\hline Model & Biosphere & Transport & $\begin{array}{l}\text { Resolution of the model run } \\
(\text { long } \times \text { lat } \times \text { time } \times \text { layers })\end{array}$ \\
\hline CT2013B & CASA/GFED2 and CASA/GFED3.1 & TM5 / ERA-Interim, ECMWF & $3^{\circ} \times 2^{\circ} \times 3 \mathrm{~h} \times 25$ \\
UoE & CASA/GFED & GEOS-Chem / GEOS5 & $5^{\circ} \times 4^{\circ} \times 3 \mathrm{~h} \times 47$ \\
MACC 13.1 & ORCHIDEE & LMDZ / ECMWF & $3.75^{\circ} \times 1.9^{\circ} \times 3 \mathrm{~h} \times 39$ \\
\hline
\end{tabular}

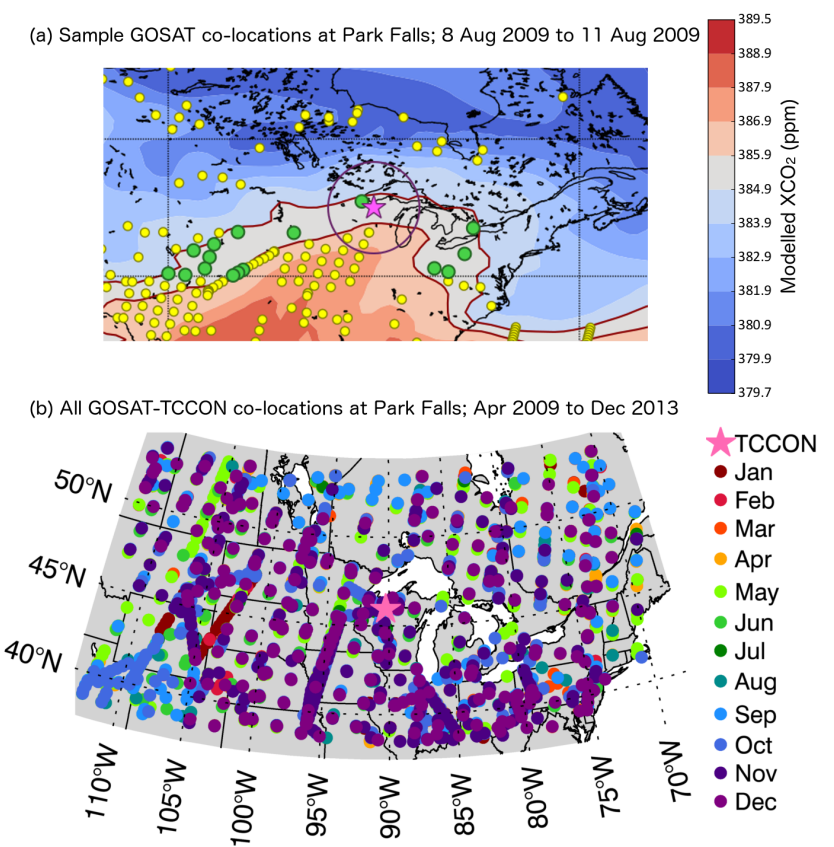

Figure 2. (a) An example of the GOSAT-TCCON co-locations using the NOAA/Basu technique (Guerlet et al., 2013a) at Park Falls TCCON station (Wisconsin, USA). All GOSAT/ACOS soundings from 8 to 11 August 2009 are shown with filled circles. The dynamical criterion based on the modelled $\mathrm{XCO}_{2}$ fields and a $0.5 \mathrm{ppm}$ tolerance from the value at the TCCON location limits the number of co-located satellite soundings (green circles). The soundings marked with yellow symbols did not pass the co-location criteria. (b) All co-located GOSAT/ACOS soundings from April 2009 to December 2013 at the Park Falls TCCON, coloured according to the month of observation.
Park Falls are mapped in Fig. 2b, which shows that the exact locations of the co-located GOSAT soundings are to a minor extent dependent on the season.

The relatively large geographical limits used in the NOAA/Basu co-location method can allow, in principle, two or more TCCON stations to simultaneously be co-located with a GOSAT sounding if the modelled spatial gradient of $\mathrm{XCO}_{2}$ is within the tolerance value. This gives us a good opportunity to test the accuracy of the co-location method in practice, using only TCCON stations independently of any GOSAT soundings. In this test, we applied the same colocation criteria and an $\mathrm{XCO}_{2}$ gradient tolerance of $1.0 \mathrm{ppm}$ to all TCCON stations and looked for any co-located measurements between different TCCON stations. We used the $1.0 \mathrm{ppm}$ tolerance instead of $0.5 \mathrm{ppm}$ because if a GOSAT sounding is simultaneously co-located with two different TCCON stations, the two stations can differ by up to $1.0 \mathrm{ppm}$. Then, we examined whether the measured $\mathrm{XCO}_{2}$ at the colocated sites exceeded the given tolerance. For example, the European TCCON stations at Karlsruhe and Garmisch had co-located soundings on 256 days during years 2009-2014, from which 87 were days when the difference in their dailyaveraged $\mathrm{XCO}_{2}$ was larger than $1.0 \mathrm{ppm}$. Similarly, for Karlsruhe and Bremen, the daily averages differed by more than $1.0 \mathrm{ppm}$ on 67 days from a total of 127 co-located days. The larger fraction of days when the co-location method might not work in the latter case is likely due to local pollution at the Bremen TCCON site that is potentially not captured by modelled $\mathrm{XCO}_{2}$ fields. Guided by these results, the colocation method is identified as one potential error source in the seasonal cycle analysis, and its impact on the results is estimated in Sect. 5.1. 

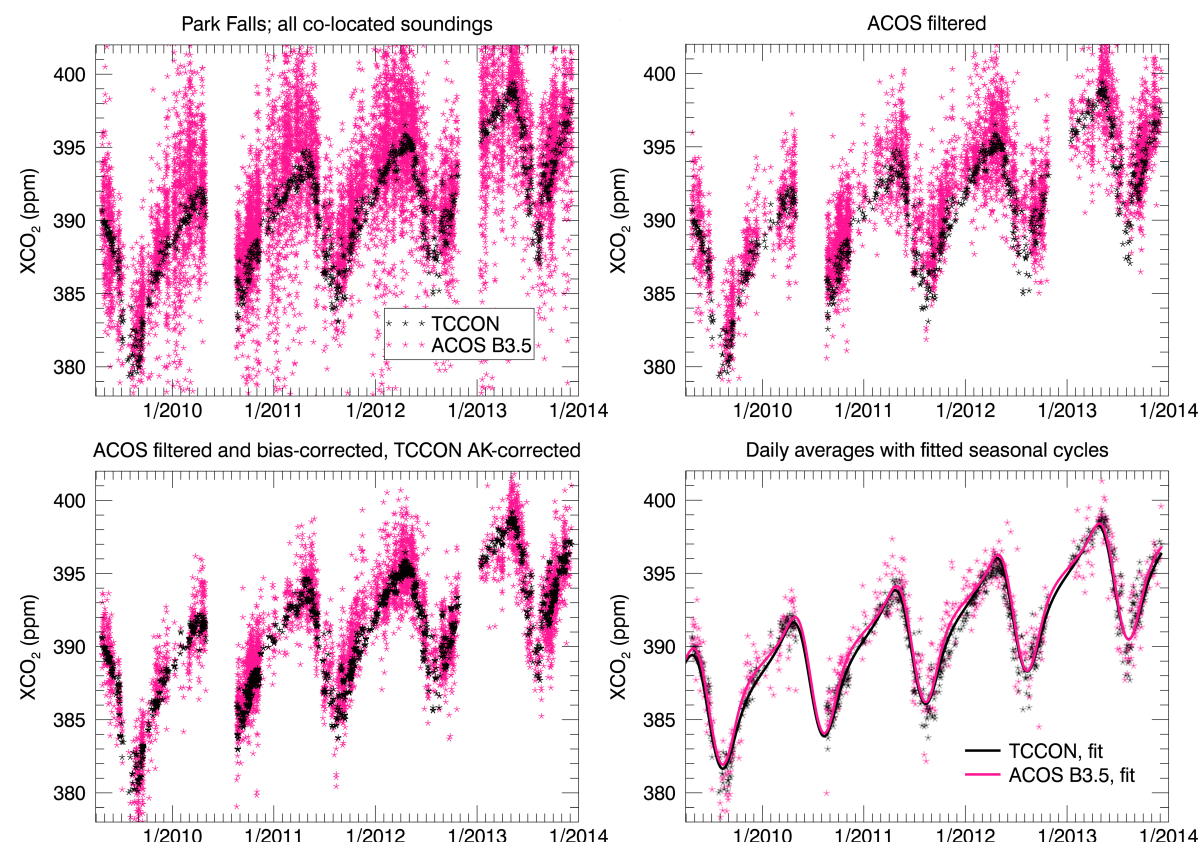

Figure 3. An example of data processing and the seasonal cycle fitting procedure at Park Falls. The upper left panel shows time series of the retrieved $\mathrm{XCO}_{2}$ for all co-located TCCON (black) and GOSAT/ACOS (pink) soundings. The upper right figure shows only those ACOS L2 soundings that pass the post-processing filters. The lower left figure has bias correction applied for ACOS data and averaging kernel correction considered for TCCON soundings. The lower right panel shows the daily averages of $\mathrm{XCO}_{2}$ and the respective seasonal cycle fits.

\subsection{Data processing}

We used GOSAT/ACOS B3.5 level 2 data, which have been pre-filtered and cloud-screened (O'Dell et al., 2012; Taylor et al., 2012). All available ACOS soundings (land $\mathrm{H}$ and $\mathrm{M}$ gain, ocean glint) were used at each site, but for the northern mid-latitude sites, most, if not all, data were land gain $\mathrm{H}$ soundings (see Table 3 ). After the co-location, the ACOS soundings were filtered using a post-processing filter that removed bad data, such as data from poor spectral fits or containing larger amounts of aerosols, from the soundings. In total, filtering removed $47 \%$ of the $\mathrm{H}$ gain over land, $45 \%$ of $\mathrm{M}$ gain over land, and $40 \%$ of glint soundings that had been co-located with the TCCON sites considered in this study. An example of the effect of post-processing filtering is shown in Fig. 3, in the upper panels.

We also corrected for the known retrieval biases via a multi-parameter linear regression similar to Wunch et al. (2011b) but optimized for B3.5. The optimization is done with respect to all TCCON data and an average of eight inversion-based models. Model results are used for bias correction only when the models agree with each other to within $1 \mathrm{ppm}$ of the total $\mathrm{XCO}_{2}$ for a given sounding. The bias correction algorithm performed a correction to the retrieved $\mathrm{XCO}_{2}$ based on different parameters. Bias correction is optimized globally, not regionally, but separately for land (nadir, gains $\mathrm{H}$ and $\mathrm{M}$ ) and ocean (glint) soundings.
When comparing two different remote-sensing measurements, the results are not comparable before the difference due to the retrieval averaging kernels has been considered (Rodgers and Connor, 2003). Since the averaging kernels of TCCON and ACOS are quite similar, it was sufficient to follow the correction introduced by Wunch et al. (2011b) and further implemented in Nguyen et al. (2014). The effects of the averaging kernel correction for TCCON and bias correction for GOSAT/ACOS soundings are presented in Fig. 3, in the lower left panel. For model results, the averaging kernel corrections were not applied.

Finally, we calculated daily averages of co-located GOSAT/ACOS and TCCON retrievals. This way, days with multiple soundings are not more dominant in the seasonal cycle fit than the days with fewer soundings. Time series of daily averages are shown in Fig. 3, in the lower right panel.

\subsection{Seasonal cycle}

In what follows, we parameterize the seasonal cycle of $\mathrm{XCO}_{2}$ as a skewed sine wave with an upward trend and find that it is generally a good model for the time series of $\mathrm{XCO}_{2}$ in the Northern Hemisphere. We fitted an average seasonal cycle to the daily $\mathrm{XCO}_{2}$ averages using the following six-parameter function 
Table 2. Parameters defining the fitted seasonal cycle functions of co-located TCCON and ACOS soundings at Park Falls.

\begin{tabular}{lrrrrrr}
\hline Retrieval & $a_{0}(\mathrm{ppm})$ & $a_{1}\left(\mathrm{ppm} \mathrm{day}^{-1}\right)$ & $a_{2}(\mathrm{ppm})$ & $a_{3}$ (days) & $a_{4}$ & $a_{5}$ (days) \\
\hline TCCON & 384.5 & 0.006050 & -4.224 & -111.4 & 0.6803 & -307.9 \\
ACOS & 384.8 & 0.005904 & -4.311 & -112.2 & 0.7585 & -268.5 \\
\hline
\end{tabular}

$$
\begin{aligned}
f(t) & =a_{0}+a_{1} t+a_{2} \sin \left(\omega\left[t-a_{3}\right]\right. \\
& \left.+\cos ^{-1}\left[a_{4} \cos \left(\omega\left[t-a_{5}\right]\right)\right]\right)
\end{aligned}
$$

where $t$ is the time in days and $\omega=2 \pi / T$, where $T$ is 365 days. The first two terms with the parameters $a_{0}$ and $a_{1}$ (denoting the average growth rate) fit for a linear trend, and the third term, a sine wave with a time-dependent phase, fits for the seasonal cycle parameters $a_{2}-a_{5}$. As an example, we give the parameters for both TCCON and ACOS fits at Park Falls in Table 2. In particular, $2\left|a_{2}\right|$ denotes the peak-to-peak amplitude of the sine wave and is, from here forwards, used to define the seasonal cycle amplitude. The nonlinear least squares fit was solved using a standard gradient-expansion algorithm. For Park Falls, the seasonal cycle fits for TCCON and ACOS are shown in Fig. 3, lower right panel, and the resulting seasonal cycle amplitude is $8.4 \pm 0.1 \mathrm{ppm}$ for TC$\mathrm{CON}$, and $8.6 \pm 0.2 \mathrm{ppm}$ for ACOS. The errors of the fitted parameters are driven by the standard deviations $\sigma$ of each daily $\mathrm{XCO}_{2}$, initially requiring $\sigma_{\mathrm{ACOS}} \geq 1.5 \mathrm{ppm}$ and $\sigma_{\mathrm{TCCON}} \geq 0.3 \mathrm{ppm}$. Because the true errors in daily-averaged $\mathrm{XCO}_{2}$ are not well known, we scaled the $\sigma$ of each dailyaveraged $\mathrm{XCO}_{2}$ by multiplying them with the minimized quantity $\chi$ to yield $\chi^{2}=1$ from the least squares fit. For TCCON data fits, the original $\chi^{2}$ values varied between $2<$ $\chi^{2}<10$, while for ACOS, the values were typically $\chi^{2}<1$, which implies that the initial errors $\sigma_{\text {TCCON }}$ may have been underestimated and $\sigma_{\text {ACOS }}$ overestimated. The fitting errors are purely statistical and do not take into account systematic errors in the data. A more traditional Fourier series fit with an annual and semi-annual cycle (Wunch et al., 2013) was also tried, and the fitted seasonal cycle amplitudes were virtually identical (well within the fitting errors), but because some strange behaviour during unobserved times of year could result, we opted for the fit in Eq. (1). To ensure that the amplitude and phase of the seasonal cycle were not determined largely by the fit function, we assessed the fit-minus-data residuals for both TCCON and ACOS and could not identify any systematic signatures in the residuals.

We recognize that there will be interannual variability in some or all of the fitted parameters, and that our results can be affected by that variability; especially we can expect sites with shorter co-located time series to be more sensitive. However, we do not fit for interannual variability because we are interested in identifying potential systematic errors in the average seasonal cycle captured by GOSAT and, in particu- lar, the ACOS retrieval system. For the purposes of evaluating the average seasonal cycle of $\mathrm{XCO}_{2}$, it is important to compare observations from the same time interval, which we take into account by co-locating the observations from TCCON and GOSAT.

\section{Results and discussion}

\subsection{Evaluation against TCCON}

Seasonal cycles for co-located TCCON and GOSAT/ACOS $\mathrm{B} 3.5 \mathrm{XCO}_{2}$ soundings were studied at 12 TCCON sites in the Northern Hemisphere. Detrended average seasonal cycles for both retrievals at each site are shown in Fig. 4. Detrending removed a linear trend, i.e. $\mathrm{XCO}_{2}$ average growth rate, that varied between 1.88 and 2.39 ppm year $^{-1}$ for ACOS and between 2.03 and 2.58 ppm year $^{-1}$ for TCCON retrievals, depending on the site. We estimated the sensitivity of the average seasonal cycle parameters of Eq. (1) to the fitted trend from the error covariance matrix associated to the best-fit parameters. The error in the trend was generally weakly negatively correlated with the error in the seasonal cycle amplitude, for both TCCON and ACOS. The phase-related parameters $a_{3}-a_{5}$ were not correlated with the trend. Therefore, the error from removing the trend should statistically have little effect on the parameters of the average seasonal cycle. Descriptive fit parameters together with the associated errors are collected in Table 3. Instead of showing the fitted values for the three parameters $a_{3}-a_{5}$ of the phase term in Eq. (1), the average dates of annual maximum and minimum $\mathrm{XCO}_{2}$ are listed.

The global average growth rate in $\mathrm{CO}_{2}$ is accurately captured by long-term ground-based measurements of $\mathrm{CO}_{2}$ concentration, such as the Mauna Loa record (Keeling et al., 1976). Global annual trends for the years 20092013 varied between 1.66 and 2.53 ppm year $^{-1}$ (Ed Dlugokencky and Pieter Tans, NOAA/ESRL, www.esrl.noaa. gov/gmd/ccgg/trends/, 30 March 2015). The accuracy of the TCCON-inferred regional $\mathrm{XCO}_{2}$ growth rates is not precisely known, though agreement of $0.1-0.2$ ppm year $^{-1}$ in the global growth rate has been obtained via assimilation of TCCON data in an inverse modelling framework (Chevallier et al., 2011). According to Table 3, GOSAT shows a slightly lower $\mathrm{XCO}_{2}$ growth rate than TCCON at many validation sites, of order 0.2 ppm year $^{-1}$ (around 10\%). Only at JPL, the trend fitted for GOSAT is modestly larger than that of TCCON. There are several explanations for this. Firstly, the 
Table 3. Parameters describing the $\mathrm{XCO}_{2}$ seasonal cycle for TCCON and bias-corrected GOSAT/ACOS B3.5. The fraction of gain $\mathrm{H}$ soundings over land is also shown. The validation sites are sorted according to their latitude.

\begin{tabular}{|c|c|c|c|c|c|c|c|}
\hline Site & $\begin{array}{l}\text { Time series } \\
\text { (month/year) }\end{array}$ & Retrieval & $\begin{array}{l}\text { Growth rate } \\
\left(\text { ppm year }^{-1}\right)\end{array}$ & $\begin{array}{l}\text { Amplitude } \\
\text { (ppm) }\end{array}$ & $\begin{array}{l}\text { Date of } \\
\max . \mathrm{XCO}_{2}\end{array}$ & $\begin{array}{l}\text { Date of } \\
\min . \mathrm{XCO}_{2}\end{array}$ & $\begin{array}{r}\text { Fraction of } \\
\text { land gain } \mathrm{H}\end{array}$ \\
\hline \multirow[t]{2}{*}{ Izaña } & \multirow[t]{2}{*}{ May/2009-Oct/2013 } & TCCON & $2.41 \pm 0.02$ & $5.3 \pm 0.1$ & 16 May & 19 Sep & \\
\hline & & GOSAT & $2.22 \pm 0.04$ & $5.3 \pm 0.2$ & 18 May & $17 \mathrm{Sep}$ & $12.2 \%$ \\
\hline \multirow[t]{2}{*}{ Saga } & \multirow[t]{2}{*}{ Aug/2011-Oct/2013 } & TCCON & $2.39 \pm 0.09$ & $6.7 \pm 0.2$ & 7 May & $13 \mathrm{Sep}$ & \\
\hline & & GOSAT & $1.92 \pm 0.26$ & $6.7 \pm 0.4$ & $28 \mathrm{Apr}$ & 14 Sep & $77.7 \%$ \\
\hline \multirow[t]{2}{*}{ JPL } & \multirow{2}{*}{ May/2011-Jun/2013 } & TCCON & $2.34 \pm 0.07$ & $5.1 \pm 0.2$ & 2 May & 27 Sep & \\
\hline & & GOSAT & $2.39 \pm 0.11$ & $4.6 \pm 0.3$ & 21 May & $25 \mathrm{Sep}$ & $87.2 \%$ \\
\hline \multirow[t]{2}{*}{ Tsukuba } & \multirow[t]{2}{*}{ Aug/2011-Dec/2013 } & TCCON & $2.58 \pm 0.10$ & $5.7 \pm 0.2$ & $23 \mathrm{Apr}$ & $10 \mathrm{Sep}$ & \\
\hline & & GOSAT & $2.20 \pm 0.22$ & $7.3 \pm 0.5$ & $23 \mathrm{Apr}$ & 26 Aug & $91.9 \%$ \\
\hline \multirow[t]{2}{*}{ Lamont } & \multirow[t]{2}{*}{ Apr/2009-Dec/2013 } & TCCON & $2.33 \pm 0.02$ & $5.3 \pm 0.1$ & 4 May & $20 \mathrm{Sep}$ & \\
\hline & & GOSAT & $2.14 \pm 0.03$ & $5.2 \pm 0.1$ & 6 May & $15 \mathrm{Sep}$ & $96.5 \%$ \\
\hline \multirow[t]{2}{*}{ Park Falls } & \multirow[t]{2}{*}{ Apr/2009-Dec/2013 } & TCCON & $2.21 \pm 0.03$ & $8.4 \pm 0.1$ & $22 \mathrm{Apr}$ & 15 Aug & \\
\hline & & GOSAT & $2.16 \pm 0.04$ & $8.6 \pm 0.2$ & $27 \mathrm{Apr}$ & 14 Aug & $100 \%$ \\
\hline \multirow[t]{2}{*}{ Garmisch } & \multirow[t]{2}{*}{ May/2009-Oct/2013 } & TCCON & $2.03 \pm 0.04$ & $6.6 \pm 0.1$ & $25 \mathrm{Mar}$ & 27 Aug & \\
\hline & & GOSAT & $1.90 \pm 0.07$ & $5.7 \pm 0.2$ & 17 Apr & 24 Aug & $100 \%$ \\
\hline \multirow[t]{2}{*}{ Orleans } & \multirow[t]{2}{*}{ Aug/2009-Nov/2013 } & TCCON & $2.29 \pm 0.04$ & $7.3 \pm 0.1$ & $30 \mathrm{Mar}$ & 28 Aug & \\
\hline & & GOSAT & $2.04 \pm 0.07$ & $6.2 \pm 0.3$ & $13 \mathrm{Apr}$ & 22 Aug & $100 \%$ \\
\hline \multirow[t]{2}{*}{ Karlsruhe } & \multirow[t]{2}{*}{ Apr/2010-Nov/2013 } & TCCON & $2.25 \pm 0.06$ & $7.3 \pm 0.2$ & $21 \mathrm{Mar}$ & 24 Aug & \\
\hline & & GOSAT & $2.05 \pm 0.09$ & $6.5 \pm 0.2$ & $27 \mathrm{Mar}$ & 27 Aug & $100 \%$ \\
\hline \multirow[t]{2}{*}{ Bremen } & \multirow[t]{2}{*}{ Apr/2009-Apr/2013 } & TCCON & $2.21 \pm 0.06$ & $7.7 \pm 0.3$ & $8 \mathrm{Mar}$ & $3 \mathrm{Sep}$ & \\
\hline & & GOSAT & $1.88 \pm 0.09$ & $6.6 \pm 0.3$ & $10 \mathrm{Apr}$ & 24 Aug & $100 \%$ \\
\hline \multirow[t]{2}{*}{ Bialystok } & \multirow[t]{2}{*}{ Apr/2009-Oct/2013 } & TCCON & $2.18 \pm 0.03$ & $8.1 \pm 0.1$ & $16 \mathrm{Mar}$ & 18 Aug & \\
\hline & & GOSAT & $1.99 \pm 0.06$ & $7.5 \pm 0.2$ & $5 \mathrm{Apr}$ & 17 Aug & $100 \%$ \\
\hline \multirow[t]{2}{*}{ Sodankylä } & \multirow[t]{2}{*}{ May/2009-Oct/2013 } & TCCON & $2.15 \pm 0.04$ & $8.7 \pm 0.3$ & $16 \mathrm{Apr}$ & 15 Aug & \\
\hline & & GOSAT & $2.05 \pm 0.09$ & $9.5 \pm 0.5$ & $24 \mathrm{Apr}$ & 17 Aug & $100 \%$ \\
\hline
\end{tabular}

JPL TCCON is located in the Los Angeles basin and therefore subject to significant local pollution that will be only partly included in the co-located GOSAT soundings. Secondly, GOSAT showing a generally lower trend than TCCON can be a sign of a potentially inaccurate correction for radiometric degradation that is caused by minor contamination of the instrument over time (Kuze et al., 2014). Lastly, time series of a little over 2 years of co-located data (like those of Saga, JPL, and Tsukuba) are arguably too short to distinguish a trend from interannual variability. However, the trend captured by GOSAT may be of minor significance compared to its measurements of the seasonal cycle: errors in capturing the trend may result in errors of the order of a few tenths of a ppm while errors in capturing the seasonal cycle may have a more significant impact, though this will depend on the detailed set-up of each inverse modelling system.

The phase of the seasonal cycle is relatively well captured by GOSAT/ACOS. The timing of the (detrended) maximum concentration varies from 8 March to 16 May for TCCON and from 27 March to 21 May for GOSAT. The satellite observes the maximum later than the TCCON at the European sites but obtains good agreement elsewhere. At the European sites, the difference extends up to 2-3 weeks and is likely connected with the biased amplitude inferred by ACOS discussed below. While the maximum occurs within 2 spring months depending on location, the minimum is more seasonally restricted, varying from 15 August to 27 September for TCCON and from 14 August to 25 September for GOSAT. During the minimum, the Northern Hemisphere receives solar light abundantly and is not snow covered, so the number of co-located soundings is larger and the minimum is well captured by the satellite, within 6 days from TCCON, except for Tsukuba and Bremen, which could be due to strong local sources of $\mathrm{CO}_{2}$ that are not correctly captured by the co-located GOSAT soundings. These values are generally in good agreement (within a few days) with Wunch et al. (2013, p. 9451), except for the TCCON seasonal cycle maximum date at the European sites Bialystok and Bremen. However, 

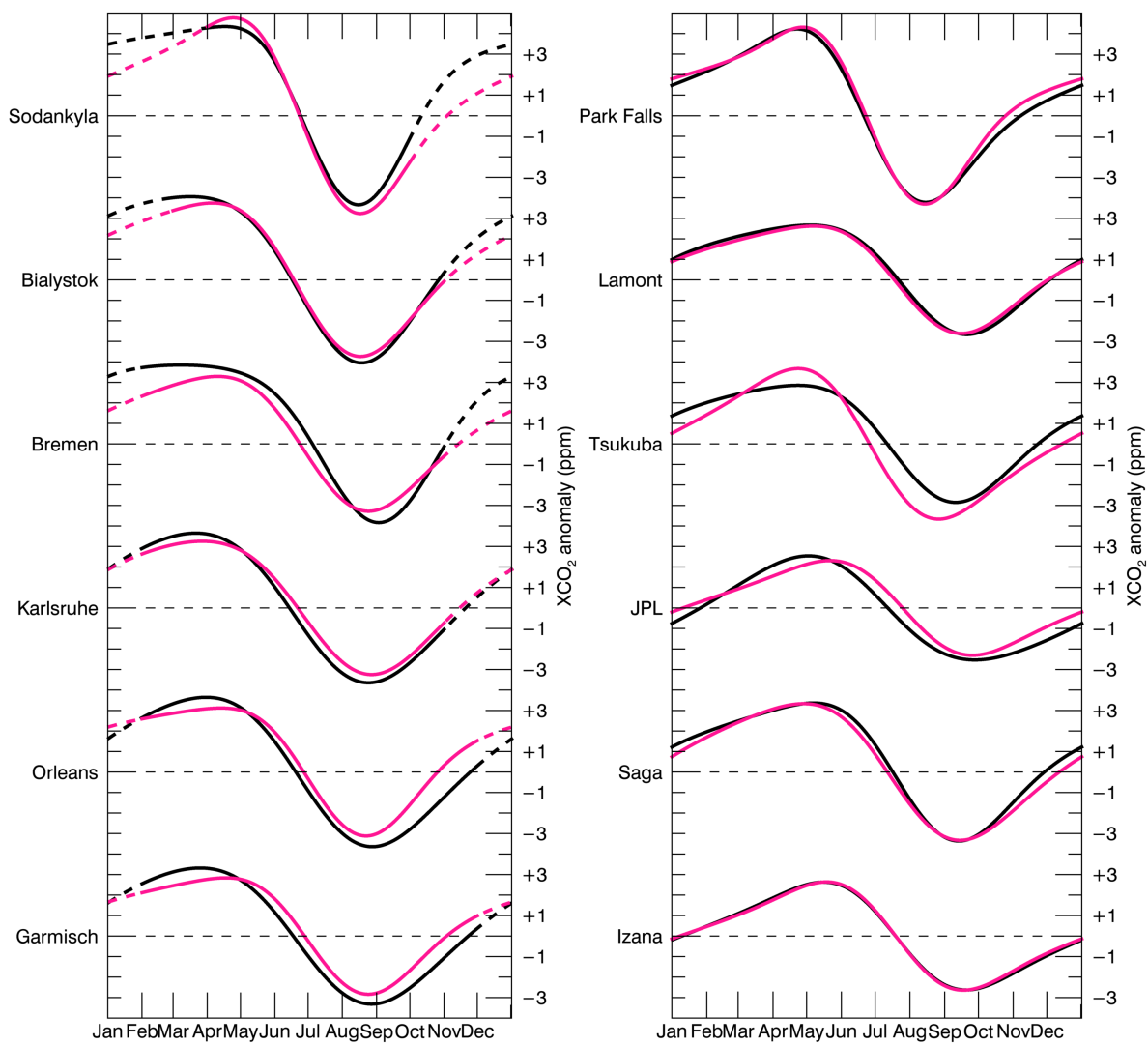

Figure 4. Detrended, best-fit seasonal cycles for GOSAT/ACOS (pink) and TCCON (black) at 12 validation sites in the Northern Hemisphere. The sites are organized according to their latitude (Sodankylä highest, Izaña lowest). The dashed lines depict the times of year with no or few co-located soundings. On the vertical axis, one tick interval corresponds to $1.0 \mathrm{ppm} \mathrm{XCO}_{2}$.

regarding the difference in the dates of the maximum, Kulawik et al. (2015) found a much smaller phase difference in Europe by calculating cross-correlation of the data points to determine the phase shift. Because our results were based on the fitted seasonal cycles instead of the actual data, we evaluated the statistical errors of the dates of the maximum and minimum $\mathrm{XCO}_{2}$ with a Monte Carlo approach, using the error covariance matrices associated with the fitted function parameters. The deviations from the fit maximum and minimum followed a normal distribution with an average $\sigma$ of 3.5 days for the TCCON maximum date and 6.1 days for ACOS maximum date, reflecting a notable uncertainty in the fitted phase and thus explaining at least partially the difference between our results and those of Kulawik et al. (2015). The corresponding average $\sigma$ for the date of the minimum were 2.2 days (TCCON) and 3.6 days (ACOS).

The seasonal cycle amplitudes are presented in Fig. 5a, in addition to Table 3 . The amplitude is captured within the error bars of the regression at four sites: Izaña, Lamont, Saga, and Park Falls. The largest absolute differences are $1.6 \mathrm{ppm}$ at Tsukuba and $1.1 \mathrm{ppm}$ at Bremen and Orleans, which are also the largest relative differences $(28,14$, and $15 \%)$. Within $1.0 \mathrm{ppm}$ difference, the amplitude is captured at all other sites. It should be noted that Tsukuba only has data for 2 years and therefore substantial uncertainty in both the trend and amplitude, whereas the Bremen and Orleans sites have sufficient data for evaluating an average seasonal cycle. A closer inspection of Figs. 4 and 5a reveals that the amplitude seen by GOSAT/ACOS is systematically shallower than TCCON at all five TCCON sites in continental Europe. This bias appears to be regionally very concentrated, because at the Northern European site Sodankylä, GOSAT captures the seasonal cycle reasonably well (within $0.8 \mathrm{ppm}$ ), considering the site suffers from data (and sunlight) deficiency in winter. Kulawik et al. (2015) noted the low bias as well, although they grouped all TCCON sites within latitudes $46-53^{\circ} \mathrm{N}$ together and found that, at this latitude range, the seasonal cycle of ACOS was biased low by $0.7 \pm 0.7 \mathrm{ppm}$.

We explored several possible explanations for the lowbiased seasonal cycle amplitude over continental Europe. First, we repeated the analysis using GOSAT/ACOS B3.4 retrievals (instead of B3.5), which have two constant aerosol types in the retrieval, different filtering, and bias correction. This did not have a systematic effect: the seasonal cycle amplitude of GOSAT increased at Bremen $(+0.3 \mathrm{ppm})$ and 

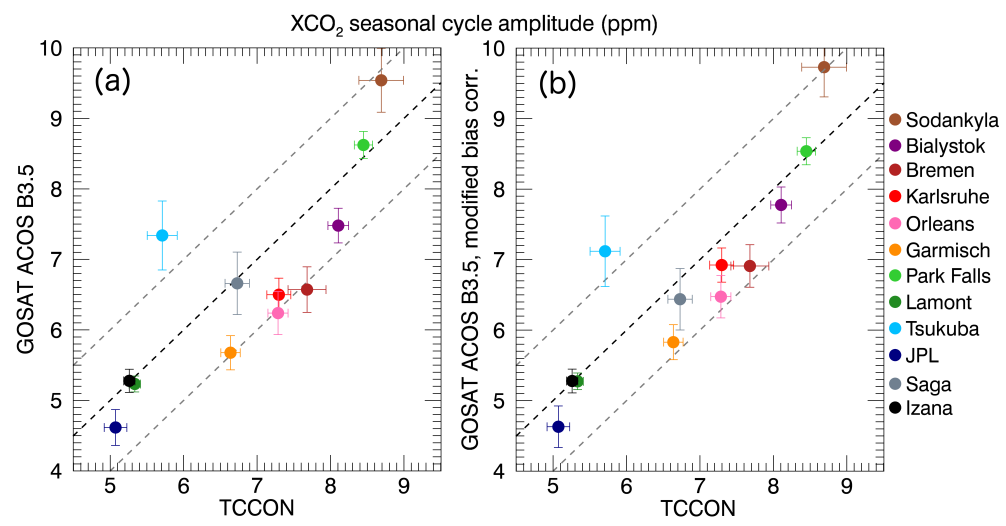

Figure 5. Seasonal cycle amplitude for ACOS (vertical axis) and TCCON (horizontal axis) for all the $12 \mathrm{NH}$ sites used in the validation. The dashed black line corresponds to the one-to-one line, and the grey lines denote $\pm 1.0 \mathrm{ppm}$. Panel (a) shows the standard bias-corrected ACOS B3.5, and panel (b) shows ACOS B3.5 with a modified bias correction (see Sect. 5.1 for details).

Orleans $(+0.5 \mathrm{ppm})$ and decreased at Bialystok $(-0.2 \mathrm{ppm})$, Garmisch ( $-0.2 \mathrm{ppm})$, and Karlsruhe ( $-0.4 \mathrm{ppm})$.

Next, we introduced variations to the co-location method to quantify its impact to the seasonal cycle amplitude. Our default co-location technique was the NOAA/Basu method with $0.50 \mathrm{ppm} \mathrm{CO}_{2}$ gradient, maximum latitude difference $7.5^{\circ}$, and longitude $22.5^{\circ}$. We experimented with four modifications to it: (1) latitude $5.0^{\circ}$, longitude $15^{\circ}$, (2) latitude $2.5^{\circ}$, longitude $7.5^{\circ}$, (3) $0.25 \mathrm{ppm} \mathrm{CO}_{2}$ gradient, and (4) $1.0 \mathrm{ppm} \mathrm{CO} 2$ gradient. The latter increased the number of co-located points while the three former reduced it by making the co-location requirement stricter. We found that a smaller longitude-latitude box and a tighter $\mathrm{CO}_{2}$ gradient led to a better match-up in terms of the seasonal cycle amplitude at Bialystok (difference only 0.1 ppm) but not in other European sites where the difference either did not change or increased. The ACOS seasonal cycle amplitude at Garmisch site turned out to be highly dependent on the co-location details, varying from 5.0 to $5.9 \mathrm{ppm}$ in these tests. The TCCON amplitudes changed typically only $0.1 \mathrm{ppm}$, but the fitting errors increased as the number of co-located soundings decreased. We also found that the co-location box dimensions had an impact on the seasonal cycle at JPL, which is located in the Los Angeles basin where large $\mathrm{CO}_{2}$ gradients could be expected. With the default technique, the amplitude for ACOS was $0.5 \mathrm{ppm}$ shallower than TCCON (10\% difference), but when decreasing the box size, the difference was reduced to $0.1 \mathrm{ppm}(2 \%)$.

In our last experiment, we tested the impact of the ACOS B3.5 bias correction for $\mathrm{H}$ gain over land; as Table 3 shows, all co-located soundings at the continental European sites were land gain $\mathrm{H}$. We found that the bias correction increased the seasonal cycle amplitude at Park Falls by 1.4 ppm, mostly due to a correction for dust aerosol optical depth and surface albedo in the $2.1 \mu \mathrm{m}$ band, but the bias correction had only a $0.1 \mathrm{ppm}$ total impact on the amplitude at the European sites. It turned out that two of the bias correction parameters (re- lated to the retrieved surface pressure and vertical $\mathrm{CO}_{2}$ gradient) made the seasonal cycle over Europe consistently shallower by $0.3-0.4 \mathrm{ppm}$, depending on the site (see Fig. $5 \mathrm{~b}$ ). However, these parameters did not affect the seasonal cycle amplitude at Park Falls or Lamont, which are the two main sites used when optimizing the ACOS bias correction. An interesting finding is that removing these two terms from the bias correction made the ACOS seasonal cycle amplitude (Fig. 5b) and trend (not shown) agree better with TCCON at 10 of the 12 sites, even though it made the scatter worse in single-sounding statistics. This implies that the bias correction might be improved by designing it based on aggregated soundings in addition to single observation statistics.

\subsection{Evaluation against other retrieval algorithms}

To further study the discrepancies of GOSAT and TCCON, we repeated the seasonal cycle analysis for four other retrieval algorithms, taking into account their individual bias corrections: RemoTeC v2.35 (Butz et al., 2011; Guerlet et al., 2013a), University of Leicester (UoL) v5.1 (Cogan et al., 2012), NIES PPDF-S v.02.11 (Oshchepkov et al., 2013b), and NIES v02.21 (Yoshida et al., 2013), which is the operational GOSAT retrieval algorithm with the bias correction applied. The seasonal cycle amplitude, the trend, and the days of maximum and minimum (detrended) $\mathrm{XCO}_{2}$ are presented in Fig. 6 together with their daily averages RMS error with respect to the TCCON fit. RemoTeC had a shorter time series than the other retrievals and was therefore not included in the Saga, JPL, and Tsukuba results. UoL data did not include glint soundings, which may cause some differences at coastal or island sites. Also, only ACOS and NIES retrievals included a sufficient amount of co-located soundings for successfully fitting a seasonal cycle at Sodankylä.

Overall, the five algorithms performed qualitatively similarly but show notable scatter at most validation sites and in most of the fitted parameters. Also, no algorithm clearly 

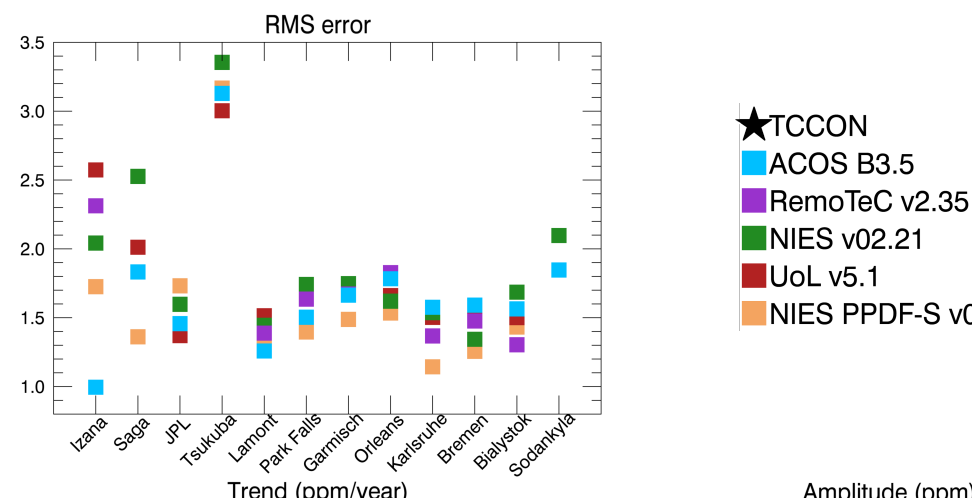

UoL v5.1

NIES PPDF-S v02.11
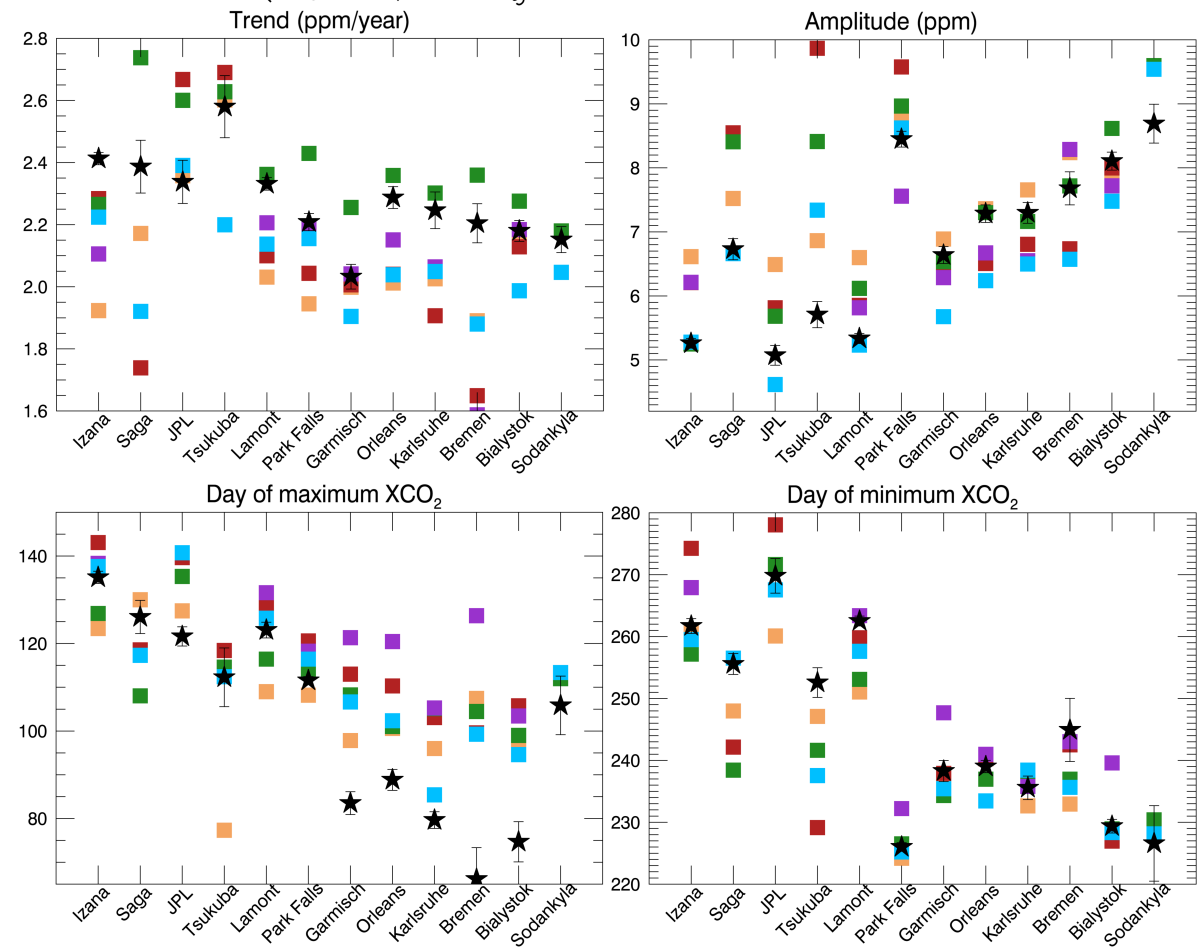

Figure 6. Comparison of the GOSAT and TCCON $\mathrm{XCO}_{2}$ time series using the following parameters: root-mean-square (RMS) error (upper left panel), average trend (middle left panel), seasonal cycle amplitude (middle right panel), and the days of maximum and minimum $\mathrm{XCO}_{2}$ (bottom row). Five retrieval algorithms were included to describe GOSAT observations. TCCON values were based on ACOS B3.5 co-located soundings. The 12 Northern Hemisphere validation sites are shown on the horizontal axis, their latitude increasing from left to right.

outperforms another. The only systematic difference is that all algorithms except NIES generally capture a smaller mean growth rate than TCCON, whereas NIES retrieves a higher trend. This may be due to different corrections for radiometric degradation in the different algorithms but could also result from other factors, such as bias correction. For example, NIES v02.21 and NIES PPDF-S v.02.11 have different growth rates despite the use of similar corrections for radiometric degradation. The TCCON seasonal cycle amplitude is captured by GOSAT at almost every site but by a different retrieval: as shown in Sect. 5.1, ACOS has a very good agreement with TCCON at the North American sites as well as Izaña and Saga but, in continental Europe, NIES and NIES PPDF-S perform generally the best. ACOS, RemoTeC, and
UoL all show a low-biased amplitude in continental Europe, and NIES, UoL, and NIES PPDF-S are biased high elsewhere. If considering only those sites with longer time series, the scatter between the algorithms is around $1 \mathrm{ppm}$.

The maximum and minimum days of the seasonal cycle reflect the drawdown season and are dependent on latitude and climate region. Both TCCON and GOSAT capture an earlier start of drawdown at the continental European sites compared to the other sites, the latest start being at the southernmost site, Izaña. The ACOS and NIES PPDF-S algorithms appear to be generally best in phase with TCCON regarding the date of maximum $\mathrm{XCO}_{2}$. At the continental European sites, GOSAT and TCCON fits for the maximum day differ by several weeks, TCCON being systematically earlier. The 


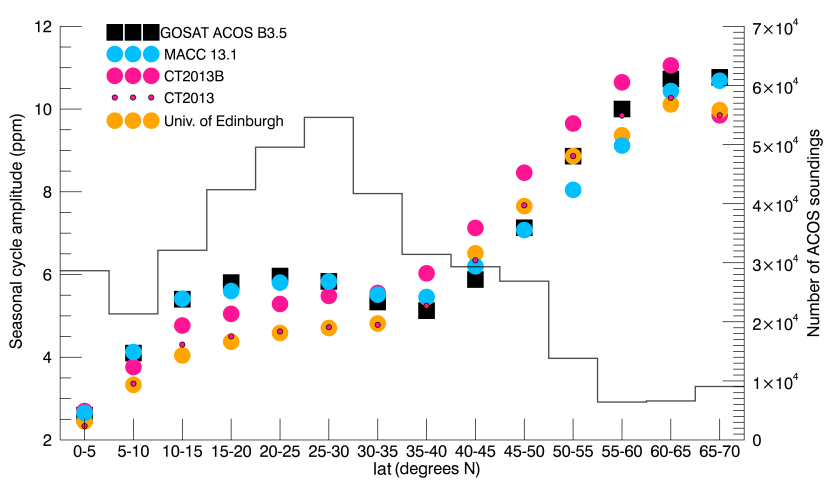

Figure 7. Latitudinal dependence of the seasonal cycle amplitude for bias-corrected ACOS B3.5 soundings and for three models resampled at the satellite soundings. For CarbonTracker, we show both CT2013 and CT2013B results, their difference being a major correction in the TM5 transport model. The left vertical axis shows the seasonal cycle amplitude in ppm, while the right vertical axis indicates the number of soundings that fall within each $5^{\circ}$ latitude band (black line).

minimum is better captured by all retrievals, with the spread varying from a few days to about 20 days; the performance of the individual algorithms is very site-specific.

Since none of the retrieval algorithms clearly outperformed the others at every TCCON site, we repeated the analysis for the ensemble median algorithm EMMA (Reuter et al., 2013), which combines all individual retrievals into one data set of median $\mathrm{XCO}_{2}$ values. Even though EMMA had the smallest RMS error at four TCCON sites overall, it did not perform systematically better or worse than the individual retrieval algorithms in capturing the seasonal cycle of $\mathrm{XCO}_{2}$.

\subsection{Evaluation against models}

The seasonal cycle amplitude of GOSAT/ACOS B3.5 was also compared to the inverse model systems MACC 13.1, CT2013B, and UoE in the Northern Hemisphere. As described in Sect. 3.2, these models have been optimized against assimilated flask and in situ $\mathrm{CO}_{2}$ measurements, though not exactly the same data sets nor using the exact same weighting. For the comparison, latitudes from 0 to $70^{\circ}$ were divided into $5^{\circ}$ latitude bins (see Fig. 1 for the map), and the GOSAT/ACOS soundings within one latitude bin were collected into a single time series. The seasonal cycle was fitted on the daily averages of GOSAT/ACOS $\mathrm{XCO}_{2}$ and the resampled models. The resulting seasonal cycle amplitudes are shown in Fig. 7. The amplitude increases significantly from the tropics towards high latitudes for both GOSAT and the models. Although the results are qualitatively similar, the models can show close to $2 \mathrm{ppm}$ differences within latitude bands. ACOS is in excellent agreement to MACC from 0 to $50^{\circ} \mathrm{N}$, whereas CT2013B and UoE have a shallower seasonal cycle from the tropics up to $35^{\circ} \mathrm{N}$. Differences in the

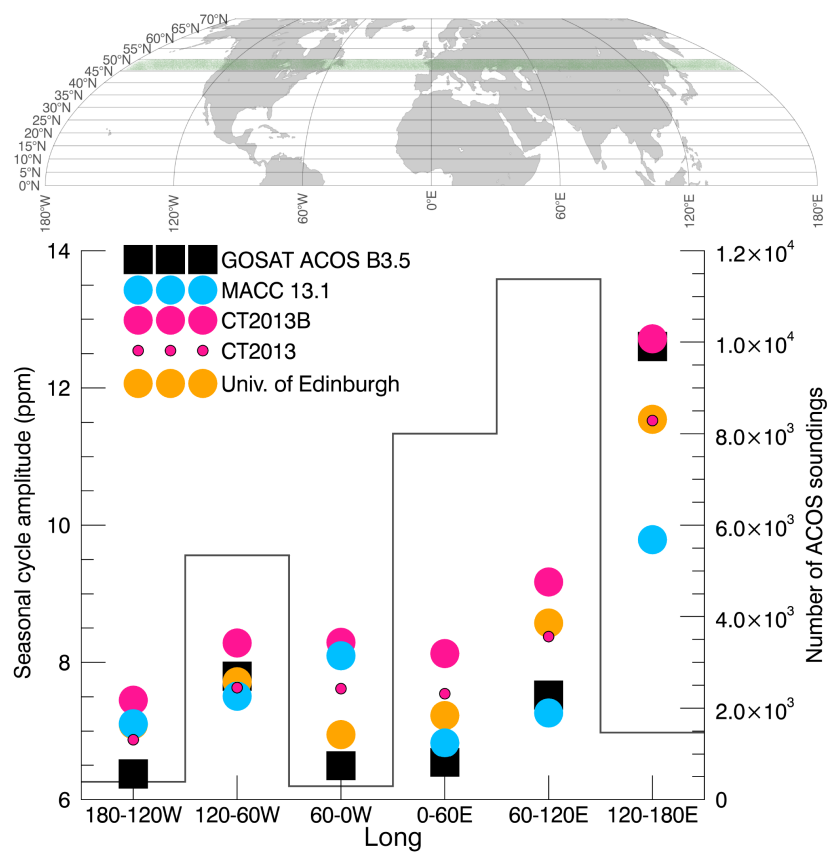

Figure 8. Longitudinal dependence of the seasonal cycle amplitude within the latitude band $45-50^{\circ} \mathrm{N}$. The left vertical axis shows the seasonal cycle amplitude in ppm, while the right vertical axis indicates the number of soundings that fall within each $60^{\circ}$ longitude bin. This latitude zone is highlighted in the world map where also the locations of the continents can be seen.

model seasonal cycle can be caused by a number of error sources, including their prior, transport, and inversion. Tropical and subtropical latitudes include large regions where the data constraint is weaker; therefore, the land surface prior (and its particular implementation) may impact the inversion results more than at those regions where the measurement network is dense. Both UoE and CT2013B use a variant of CASA as their prior biospheric flux model, as presented in Table 1 (in fact, CT2013B uses a unique combination of two flavours of CASA; Andy Jacobson, personal communication, 17 April 2015). Even though different versions of CASA can differ in their seasonal cycle magnitude, our results may imply that the seasonal cycle of CASA fluxes is too shallow in some tropical regions or biomes. We first did the comparison using earlier versions of CarbonTracker (CT2011 and CT2013) and found that CarbonTracker and UoE results were nearly identical in these regions (see CT2013 and UoE in Figs. 7 and 8), which was surprising because the two models were different in every aspect (transport, in situ data selection, inversion) except for their prior biospheric fluxes. However, a significant correction to the transport model's vertical mixing was introduced in CT2013B. This led to an increase of about $0.5 \mathrm{ppm}$ in the CarbonTracker's seasonal cycle amplitude at all latitudes.

At $50-60^{\circ} \mathrm{N}$ in Fig. 7, ACOS agrees better with UoE and CT2013B. From 60 to $70^{\circ}$, ACOS has a higher seasonal cy- 
cle amplitude than most models. A similar result was also obtained by Belikov et al. (2014) using GOSAT/NIES v02.00 retrievals, NIES transport model, and LMDZ model. However, at high boreal latitudes, the satellite observations are associated with larger errors that are not reflected in the purely statistical fitting errors. ACOS results at these latitudes should therefore be interpreted with caution.

We tested how the ACOS bias correction and model averaging kernel correction affected the latitudinally averaged seasonal cycle amplitudes. The ACOS bias correction decreased the amplitude about $0.5 \mathrm{ppm}$ at latitudes $10-40^{\circ} \mathrm{N}$ but increased the amplitude at $40-70^{\circ} \mathrm{N}$. The maximum increase was $1.0 \mathrm{ppm}$ at latitudes $50-60^{\circ} \mathrm{N}$, implying that before the bias correction, ACOS was in better agreement with MACC at these latitudes, but that after the bias correction, ACOS agreed better with UoE and CT2013B. Even though validation against models is part of the ACOS bias correction, the TCCON sites are likely to dominate the bias correction at mid-latitudes. We studied the potential seasonal impact of the averaging kernel correction for CT2013B. We found that the averaging kernel correction systematically decreased the model seasonal cycle amplitude in the Northern Hemisphere by $0.15 \mathrm{ppm}$ on average. Overall, these changes are minor and do not affect our general conclusions about the model comparisons.

The latitudinal dependence of the $\mathrm{CO}_{2}$ seasonal cycle amplitude has been previously shown e.g. in "the flying carpet" plot presented by Conway et al. (1994, Fig. 4), but we would like to emphasize that the amplitude can also depend on longitude. Especially in the mid-latitudes, its increase from west to east is notable; this is demonstrated in Fig. 8 for latitude band $45-50^{\circ} \mathrm{N}$, where the seasonal cycle amplitude of GOSAT/ACOS is $6.4 \mathrm{ppm}$ over the longitudes $180-120^{\circ} \mathrm{W}$ and is doubled at $120-180^{\circ} \mathrm{E}$. The increased seasonal cycle may be due to the large seasonal sink of the boreal forests, accrued in the total column as the observation point is moved eastward, though large-scale dynamics may also play a role. These GOSAT observations considered were taken over land, so in practice this means that the seasonal cycle amplitude is dampened from eastern Asia over the North Pacific Ocean to the northwestern United States. In the lower troposphere, this dampening above $30^{\circ} \mathrm{N}$ latitude was shown by Nakazawa et al. (1992) who analysed a 3-year time series (1984-1986) of $\mathrm{CO}_{2}$ measurements onboard container ships. The model results in Fig. 8 show a similar pattern of amplitude enhancement towards east, albeit the seasonal cycle amplitude of MACC is $2-3 \mathrm{ppm}$ shallower compared to those of the other models and ACOS in eastern Asia. Despite this large discrepancy in the east where the data volume is small (see Fig. 8, right vertical axis), the zonally averaged seasonal cycle amplitudes of MACC and ACOS agree within $0.1 \mathrm{ppm}$ at the same latitude band $\left(45-50^{\circ} \mathrm{N}\right)$. The CT2013B amplitudes are consistently higher than ACOS at all longitudes in Fig. 8, but they agree within $0.1 \mathrm{ppm}$ in eastern Asia. Of the three models, UoE is most consistent with ACOS, agreeing about the seasonal cycle amplitude to within $1 \mathrm{ppm}$ at these specific regions. The northern and mid-latitudinal regions of Asia are again regions where the in situ measurement coverage is very limited, which explains the large spread among the individual model results.

\section{Conclusions}

The seasonal cycle of $\mathrm{XCO}_{2}$ is profoundly connected to the biospheric fluxes that determine the global terrestrial net $\mathrm{CO}_{2}$ sink. Satellite measurements of $\mathrm{XCO}_{2}$ by GOSAT and OCO2 expand the current in situ measurement network tremendously and therefore have the potential to improve flux inversions. However, the satellite-measured seasonal cycle of $\mathrm{XCO}_{2}$ can be affected by different retrieval biases, such as biases related to seasonally varying parameters (e.g. surface albedo) and a sampling bias due to the seasonal variation in solar radiation. Mischaracterization of the seasonal cycle could lead to errors in the inverse model systems that assimilate satellite $\mathrm{CO}_{2}$ data. Motivated by this, we evaluated the seasonal cycle of GOSAT observations using ACOS B3.5 retrievals from years 2009-2013.

Three independent approaches were used for the evaluation of the $\mathrm{XCO}_{2}$ seasonal cycle: comparisons against the Total Carbon Column Observing Network (TCCON), other GOSAT retrievals (UoL v5.1, NIES v02.21, NIES PPDF$\mathrm{S}$ v.02.11, and RemoTeC v2.35), and comparisons to optimized inversion models that assimilate in situ measurements of $\mathrm{CO}_{2}$. We found that ACOS captures the seasonal cycle amplitude of TCCON with an accuracy of better than $1.0 \mathrm{ppm}$ at most of the 12 TCCON sites in the Northern Hemisphere and all four sites in the Southern Hemisphere considered in this study. As we also inferred the mean annual growth rate at each TCCON site in order to remove it, we found agreement of generally better than $0.2 \mathrm{ppm}_{\text {year }}{ }^{-1}$ in this quantity, with the ACOS-inferred growth rate most often being lower than TCCON. Over continental Europe, the seasonal cycle amplitude as measured by ACOS was biased low at all five sites, the largest difference being $1.1 \mathrm{ppm}$ at Bremen and Orleans. We also found that ACOS generally captured the seasonal cycle phase in the Northern Hemisphere within a few days, except over Europe where the differences were 2-3 weeks, with ACOS measuring the date of maximum $\mathrm{XCO}_{2}$ later than TCCON. Several other algorithms also had minor low biases in their seasonal cycle amplitudes over Europe. We explored the cause of the low bias for ACOS and found that the bias correction parameters related to the retrieved surface pressure and vertical $\mathrm{CO}_{2}$ gradient were partially responsible, explaining 16-48\% of the difference. This suggests that the bias correction might benefit from considering aggregated soundings in addition to deviations at single-sounding level. Also, the selection of the co-located soundings was found to affect the seasonal cycle amplitude at few sites. Especially at JPL, which is in the Los Angeles basin, the agreement with 
TCCON improved notably when the co-location criteria were made sufficiently tight to not include soundings taken too far from the basin.

Model comparisons at latitudes $0-70^{\circ} \mathrm{N}$ revealed that qualitatively the models and satellite observations agreed well, but also that the model-to-model differences were (at most latitude bands studied) larger than model-to-ACOS differences. From the tropics up to $50^{\circ} \mathrm{N}$, the zonally averaged seasonal cycle amplitude of ACOS was in very good agreement with MACC 13.1, while between 50 and $60^{\circ} \mathrm{N}$, ACOS agreed better with the University of Edinburgh model and CarbonTracker CT2013B. Both of the latter models had seasonal cycle amplitudes shallower than ACOS or MACC at tropical and subtropical latitudes, where the models lack direct constraints from measurements over land and are thus more affected by their prior fluxes (or by extra-tropical or ocean measurements through long-range transport). Therefore, the shallower seasonal cycle amplitude might be connected to their prior land surface models that are different variants of CASA. However, to verify this, one should investigate also the impact of transport, data assimilation, and inversion system differences. We also found that the longitudinal changes in the seasonal cycle amplitude at mid-latitudes can be notable. In particular, we showed that at $45-50^{\circ} \mathrm{N}$ latitudes, the amplitude of the GOSAT $\mathrm{XCO}_{2}$ seasonal cycle doubles from the northwestern USA to eastern Asia. The model results showed a gradient as well, although it was 13 ppm shallower, depending on the model. We also noticed that the averaging kernel correction can systematically decrease the seasonal cycle amplitude by up to $0.2 \mathrm{ppm}$.

Based on our study, the GOSAT/ACOS seasonal cycle error is of the order of $1.0 \mathrm{ppm}$ near TCCON stations and likely to be of this size in other parts of the world, though it may be influenced by the a priori accuracy of jointly retrieved parameters, such as those related to aerosols. As model-tomodel differences in the $\mathrm{XCO}_{2}$ seasonal cycle amplitude can be several ppm at regions poorly sampled by in situ measurements, GOSAT observations could potentially be used directly (without elaborate inversions) to evaluate model differences at these regions. This idea is explored in more detail in a work under preparation (Lindqvist et al., 2015).

Acknowledgements. H. Lindqvist and C. W. O'Dell wish to acknowledge support from the NASA Jet Propulsion Laboratory and the OCO-2 project, via JPL subcontract number 1439002. $\mathrm{H}$. Lindqvist also acknowledges funding from the Academy of Finland, via project number 285421. H. Boesch and R. Parker acknowledge the National Centre for Earth Observation NCEO and the ESA GHG-CCI project. F. Chevallier acknowledges the European Commission (grant agreement no. 630080, MACC III). We wish to thank the referees (Susan Kulawik and an anonymous referee), the editor Paul Wennberg, and Andy Jacobson for their comments and constructive feedback to the manuscript. We also gratefully acknowledge all the data providers. The following TCCON PIs are acknowledged for providing their $\mathrm{XCO}_{2}$ data:
David Griffith (Darwin and Wollongong), Martine De Maziere (Réunion), and Vanessa Sherlock (Lauder). We also thank Debra Wunch for providing data from Lamont and Coleen Roehl for data from Park Falls. TCCON data were obtained from the TCCON data archive at http://tccon.ornl.gov/. TCCON work at Park Falls, Lamont, and Pasadena is funded by NASA grants NNX14AI60G, NNX11AG01G, NAG5-12247, NNG05-GD07G, and NASA Orbiting Carbon Observatory Program. We are grateful to the DOE ARM program for technical support in Lamont and Jeff Ayers for technical support in Park Falls. TCCON work at Garmisch has been funded by the ESA GHG-CCI project via subcontract with the University of Bremen and by the EC within the INGOS project. CarbonTracker CT2013B results were provided by NOAA ESRL, Boulder, Colorado, USA, from the website at http://carbontracker.noaa.gov. Finally, we thank our colleagues for the use of their GOSAT retrievals: André Butz and Otto Hasekamp for RemoTeC v2.35 and Andrey Bril for NIES PPDF-S v.02.11.

Edited by: P. O. Wennberg

\section{References}

Belikov, D. A., Bril, A., Maksuytov, S., Oshchepkov, S., Saeki, T., Takagi, H., Yoshida, Y., Ganshin, A., Zhuravlev, R., Aoki, S., and Yokota, T.: Column-averaged $\mathrm{CO}_{2}$ concentrations in the subarctic from GOSAT retrievals and NIES transport model simulations, Polar Science, 8, 129-145, 2014.

Blumenstock, T., Hase, F., Schneider, M., García, O. E., and Sepúlveda, E.: TCCON data from Izaña, Tenerife, Spain, Release GGG2014R0, TCCON data archive, hosted by the Carbon Dioxide Information Analysis Center, Oak Ridge National Laboratory, Oak Ridge, Tennessee, USA. doi:10.14291/tccon.ggg2014.izana01.R0/1149295, 2014.

Buchwitz, M., Reuter, M., Schneising, O., Boesch, H., Guerlet, S., Dils, B., Aben, I., Armante, R., Bergamaschi, P., Blumenstock, T., Bovensmann, H., Brunner, D., Buchmann, B., Burrows, J. P., Butz, A., Chedin, A., Chevallier, F., Crevoisier, C. D., Deutscher, N. M., Frankenberg, C., Hase, F., Hasekamp, O. P., Heymann, J., Kaminski, T., Laeng, A., Lichtenberg, G., De Maziere, M., Noel, S., Notholt, J., Orphal, J., Popp, C., Parker, R., Scholze, M., Sussmann, R., Stiller, G. P., Warneke, T., Zehner, C., Bril, A., Crisp, D., Griffith, D. W. T., Kuze, A., O'Dell, C., Oshchepkov, S., Sherlock, V., Suto, H., Wennberg, P., Wunch, D., Yokota, T., and Yoshida, Y.: The Greenhouse Gas Climate Change Initiative (GHG-CCI): comparison and quality assessment of near-surface-sensitive satellite-derived $\mathrm{CO}_{2}$ and $\mathrm{CH}_{4}$ global data sets, Remote Sens. Environ., 162, 344-362, doi:10.1016/j.rse.2013.04.024, 2013.

Butz, A., Guerlet, S., Hasekamp, O., Schepers, D., Galli, A., Aben, I., Frankenberg, C., Hartmann, J.-M., Tran, H., Kuze, A., Keppel-Aleks, G., Toon, G., Wunch, D., Wennberg, P., Deutscher, N., Griffith, D., Macatangay, R., Messerschmidt, J., Notholt, J., and Warneke, T.: Toward accurate $\mathrm{CO}_{2}$ and $\mathrm{CH}_{4}$ observations from GOSAT, Geophys. Res. Lett., 38, L14812, doi:10.1029/2011GL047888, 2011.

Chevallier, F., Breon, F.-M., and Rayner, P. J.: Contribution of the Orbiting Carbon Observatory to the estimation of $\mathrm{CO}_{2}$ sources and sinks: Theoretical study in a variational 
data assimilation framework, J. Geophys. Res., 112, D09307, doi:10.1029/2006JD007375, 2007.

Chevallier, F., Ciais, P., Conway, T. J., Aalto, T., Anderson, B. E., Bousquet, P., Brunke, E. G., Ciattaglia, L., Esaki, Y., Fröhlich, M., Gomez, A., Gomez-Pelaez, A. J., Haszpra, L., Krummel, P. B., Langenfelds, R. L., Leuenberger, M., Machida, T., Maignan, F., Matsueda, H., Morgui, J. A., Mukai, H., Nakazawa, T., Peylin, P., Ramonet, M., Rivier, L., Sawa, Y., Schmidt, M., Steele, L. P., Vay, S. A., Vermeulen, A. T., Wofsy, S., and Worthy, D.: $\mathrm{CO}_{2}$ surface fluxes at grid point scale estimated from a global 21 year reanalysis of atmospheric measurements, J. Geophys. Res., 115, D21307, doi:10.1029/2010JD013887, 2010.

Chevallier, F., Deutscher, N. M., Conway, T. J., Ciais, P., Ciattaglia, L., Dohe, S., Fröhlich, M., Gomez-Pelaez, A. J., Griffith, D., Hase, F., Haszpra, L., Krummer, P., Kyrö, E., Labuschagne, C., Langenfelds, R., Machida, T., Maignan, F., Matsueda, H., Morino, I., Notholt, J., Ramonet, M., Sawa, Y., Schmidt, M., Sherlock, V., Steele, P., Strong, K., Sussmann, R., Wennberg, P., Wofsy, S., Worthy, D., Wunch, D., and Zimnoch, M.: Global $\mathrm{CO}_{2}$ fluxes inferred from surface air-sample measurements and from TCCON retrievals of the $\mathrm{CO}_{2}$ total column, Geophys. Res. Lett., 38, L24810, doi:10.1029/2011GL049899, 2011.

Cogan, A. J., Boesch, H., Parker, R. J., Feng, L., Palmer, P. I., Blavier, J.-F. L., Deutscher, N. M., Macatangay, R., Notholt, J., Roehl, C., Warneke, T., and Wunch, D.: Atmospheric carbon dioxide retrieved from the Greenhouse gases Observing SATellite (GOSAT): Comparison with ground-based TCCON observations and GEOS-Chem model calculations, J. Geophys. Res., 117, D21301, doi:10.1029/2012JD018087, 2012.

Conway, T. J., Tans, P. P., Waterman, L. S., Thoning, K. W., Kitzis, D. R., Masarie, K. A., and Zhang, N.: Evidence for interannual variability of the carbon cycle from the National Oceanic and Atmospheric Administration/Climate Monitoring and Diagnostics Laboratory Global Air Sampling Network, J. Geophys. Res.Atmos., 99, 22831-22855, doi:10.1029/94JD01951, 1994.

Crisp, D., Atlas, R. M., Breon, F.-M., Brown, L. R., Burrows, J. P., Ciais, P., Connor, B. J., Doney, S. C., Fung, I. Y., Jacob, D. J., Miller, C. E., O'Brien, D., Pawson, S., Randerson, J. T., Rayner, P., Salawitch, R. J., Sander, S. P., Sen, B., Stephens, G. L., Tans, P. P., Toon, G. C., Wennberg, P. O., Wofsy, S. C., Yung, Y. L., Kuang, Z., Chudasama, B., Sprague, G., Weiss, B., Pollock, R., Kenyon, D., and Schroll, S.: The orbiting carbon observatory (OCO) mission, Adv. Space Res., 34, 700-709, 2004.

Crisp, D., Fisher, B. M., O’Dell, C., Frankenberg, C., Basilio, R., Bösch, H., Brown, L. R., Castano, R., Connor, B., Deutscher, N. M., Eldering, A., Griffith, D., Gunson, M., Kuze, A., Mandrake, L., McDuffie, J., Messerschmidt, J., Miller, C. E., Morino, I., Natraj, V., Notholt, J., O’Brien, D. M., Oyafuso, F., Polonsky, I., Robinson, J., Salawitch, R., Sherlock, V., Smyth, M., Suto, H., Taylor, T. E., Thompson, D. R., Wennberg, P. O., Wunch, D., and Yung, Y. L.: The ACOS $\mathrm{CO}_{2}$ retrieval algorithm - Part II: Global $\mathrm{XCO}_{2}$ data characterization, Atmos. Meas. Tech., 5, 687-707, doi:10.5194/amt-5-687-2012, 2012.

De Maziere, M., Sha, M. K., Desmet, F., Hermans, C., Scolas, F., Kumps, N., Metzger, J.-M., Duflot, V., and Cammas, J.-P.: TCCON data from Reunion Island (La Reunion), France, Release GGG2014R0. TCCON data archive, hosted by the Carbon Dioxide Information Analysis Center, Oak
Ridge National Laboratory, Oak Ridge, Tennessee, USA, doi:10.14291/tccon.ggg2014.reunion01.R0/1149288, 2014.

Deutscher, N., Notholt, J., Messerschmidt, J., Weinzierl, C., Warneke, T., Petri, C., Grupe, P., and Katrynski, K.: TCCON data from Bialystok, Poland, Release GGG2014R0, TCCON data archive, hosted by the Carbon Dioxide Information Analysis Center, Oak Ridge National Laboratory, Oak Ridge, Tennessee, USA, doi:10.14291/tccon.ggg2014.bialystok01.R0/1149277, 2014.

Dils, B., Buchwitz, M., Reuter, M., Schneising, O., Boesch, H., Parker, R., Guerlet, S., Aben, I., Blumenstock, T., Burrows, J. P., Butz, A., Deutscher, N. M., Frankenberg, C., Hase, F., Hasekamp, O. P., Heymann, J., De Mazière, M., Notholt, J., Sussmann, R., Warneke, T., Griffith, D., Sherlock, V., and Wunch, D.: The Greenhouse Gas Climate Change Initiative (GHG-CCI): comparative validation of GHG-CCI SCIAMACHY/ENVISAT and TANSO-FTS/GOSAT $\mathrm{CO}_{2}$ and $\mathrm{CH}_{4}$ retrieval algorithm products with measurements from the TCCON, Atmos. Meas. Tech., 7, 1723-1744, doi:10.5194/amt-7-1723-2014, 2014.

Feng, L., Palmer, P. I., Bösch, H., and Dance, S.: Estimating surface $\mathrm{CO}_{2}$ fluxes from space-borne $\mathrm{CO}_{2}$ dry air mole fraction observations using an ensemble Kalman Filter, Atmos. Chem. Phys., 9, 2619-2633, doi:10.5194/acp-9-2619-2009, 2009.

Feng, L., Palmer, P. I., Yang, Y., Yantosca, R. M., Kawa, S. R., Paris, J.-D., Matsueda, H., and Machida, T.: Evaluating a 3-D transport model of atmospheric $\mathrm{CO}_{2}$ using ground-based, aircraft, and space-borne data, Atmos. Chem. Phys., 11, 27892803, doi:10.5194/acp-11-2789-2011, 2011.

Griffith, D. W. T., Deutscher, N., Velazco, V. A., Wennberg, P. O., Yavin, Y., Keppel Aleks, G., Washenfelder, R., Toon, G. C., Blavier, J.-F., Murphy, C., Jones, N., Kettlewell, G., Connor, B., Macatangay, R., Roehl, C., Ryczek, M., Glowacki, J., Culgan, T., and Bryant, G.: TCCON data from Darwin, Australia, Release GGG2014R0. TCCON data archive, hosted by the Carbon Dioxide Information Analysis Center, Oak Ridge National Laboratory, Oak Ridge, Tennessee, USA, doi:10.14291/tccon.ggg2014.darwin01.R0/1149290, 2014a.

Griffith, D. W. T., Velazco, V. A., Deutscher, N., Murphy, C., Jones, N., Wilson, S., Macatangay, R., Kettlewell, G., Buchholz, R. R., and Riggenbach, M.: TCCON data from Wollongong, Australia, Release GGG2014R0. TCCON data archive, hosted by the Carbon Dioxide Information Analysis Center, Oak Ridge National Laboratory, Oak Ridge, Tennessee, USA, doi:10.14291/tccon.ggg2014.wollongong01.R0/1149291, 2014b.

Guerlet, S., Butz, A., Schepers, D., Basu, S., Hasekamp, O. P., Kuze, A., Yokota, T., Blavier, J.-F., Deutscher, N. M., Griffith, D. W. T., Hase, F., Kyrö, E., Morino, I., Sherlock, V., Sussmann, R., Galli, A., and Aben, I.: Impact of aerosol and thin cirrus on retrieving and validating $\mathrm{XCO}_{2}$ from GOSAT shortwave infrared measurements, J. Geophys. Res.-Atmos., 118, 4887-4905, doi:10.1002/jgrd.50332, 2013a.

Guerlet, S., Basu, S., Butz, A., Krol, M., Hahne, P., Houweling, S., Hasekamp, O. P., and Aben, I.: Reduced carbon uptake during the 2010 Northern Hemisphere summer from GOSAT, Geophys. Res. Lett., 40, 2378-2383, doi:10.1002/grl.50402, 2013b.

Gurney, K. R., Law, R. M., Denning, A. S., Rayner, P. J., Baker, D., Bousquet, P., Bruhwiler, L., Chen, Y.-H., Ciais, P., Fan, S., Fung, I. Y., Gloor, M., Heimann, M., Higuchi, K., John, J., Maki, 
T., Maksyutov, S., Masarie, K., Peylin, P., Prather, M., Pak, B. C., Randerson, J., Sarmiento, J., Taguchi, S., Takahashi, T., and Yuen, C. W.: Towards robust regional estimates of $\mathrm{CO}_{2}$ sources and sinks using atmospheric transport models, Nature, 415, 626629, doi:10.1038/415626a, 2002.

Gurney, K. R., Law, R. M., Denning, A. S., Rayner, P. J., Baker, D., Bousquet, P., Bruhwiler, L., Chen, Y.-H., Ciais, P., Fan, S., Fung, I. Y., Gloor, M., Heimann, M., Higuchi, K., John, J., Kowalczyk, E., Maki, T., Maksyutov, S., Peylin, P., Prather, M., Pak, B. C., Sarmiento, J., Taguchi, S., Takahashi, T., and Yuen, C.-W.: TransCom $3 \mathrm{CO}_{2}$ inversion intercomparison: 1 . Annual mean control results and sensitivity to transport and prior flux information, Tellus B, 55, 555-579, doi:10.1034/j.16000889.2003.00049.x, 2003.

Hase, F., Blumenstock, T., Dohe, S., Groß, J., and Kiel, M.: TCCON data from Karlsruhe, Germany, Release GGG2014R1, TCCON data archive, hosted by the Carbon Dioxide Information Analysis Center, Oak Ridge National Laboratory, Oak Ridge, Tennessee, USA, doi:10.14291/tccon.ggg2014.karlsruhe01.R1/1182416, 2014.

Kawakami, S., Ohyama, H., Arai, K., Okumura, H., Taura, C., Fukamachi, T., and Sakashita, M.: TCCON data from Saga, Japan, Release GGG2014R0, TCCON data archive, hosted by the Carbon Dioxide Information Analysis Center, Oak Ridge National Laboratory, Oak Ridge, Tennessee, USA, doi:10.14291/tccon.ggg2014.saga01.R0/1149283, 2014.

Keeling, C. D., Bacastow, R. B., Bainbridge, A. E., Ekdahl, C. A., Guenther, P. R., Waterman, L. S., and Chin, J. F.: Atmospheric carbon dioxide variations at Mauna Loa observatory, Hawaii, Tellus, 28, 538-551, 1976.

Keppel-Aleks, G., Wennberg, P. O., and Schneider, T.: Sources of variations in total column carbon dioxide, Atmos. Chem. Phys., 11, 3581-3593, doi:10.5194/acp-11-3581-2011, 2011.

Keppel-Aleks, G., Wennberg, P. O., Washenfelder, R. A., Wunch, D., Schneider, T., Toon, G. C., Andres, R. J., Blavier, J.-F., Connor, B., Davis, K. J., Desai, A. R., Messerschmidt, J., Notholt, J., Roehl, C. M., Sherlock, V., Stephens, B. B., Vay, S. A., and Wofsy, S. C.: The imprint of surface fluxes and transport on variations in total column carbon dioxide, Biogeosciences, 9, 875891, doi:10.5194/bg-9-875-2012, 2012.

Kivi, R., Heikkinen, P., and Kyrö, E.: TCCON data from Sodankylä, Finland, Release GGG2014R0, TCCON data archive, hosted by the Carbon Dioxide Information Analysis Center, Oak Ridge National Laboratory, Oak Ridge, Tennessee, USA, doi:10.14291/tccon.ggg2014.sodankyla01.R0/1149280, 2014.

Kulawik, S. S., Wunch, D., O’Dell, C., Frankenberg, C., Reuter, M., Oda, T., Chevallier, F., Sherlock, V., Buchwitz, M., Osterman, G., Miller, C., Wennberg, P., Griffith, D. W. T., Morino, I., Dubey, M., Deutscher, N. M., Notholt, J., Hase, F., Warneke, T., Sussmann, R., Robinson, J., Strong, K., Schneider, M., and Wolf, J.: Consistent evaluation of GOSAT, SCIAMACHY, CarbonTracker, and MACC through comparisons to TCCON, Atmos. Meas. Tech. Discuss., 8, 6217-6277, doi:10.5194/amtd-86217-2015, 2015.

Kuze, A., Suto, H., Nakajima, M., and Hamazaki, T.: Thermal and near infrared sensor for carbon observation Fourier-transform spectrometer on the greenhouse gases observing satellite for greenhouse gases monitoring, Appl. Optics, 48, 6716-6733, 2009.
Kuze, A., Taylor, T. E., Kataoka, F., Bruegge, C. J., Crisp, D., Harada, M., Helmlinger, M., Inoue, M., Kawakami, S., Kikuchi, N., Mitomi, Y., Murooka, J., Naitoh, M., O’Brien, D. M., O’Dell, C. W., Ohyama, H., Pollock, H., Schwandner, F. M., Shiomi, K., Suto, H., Takeda, T., Tanaka, T., Urabe, T., Yokota, T., and Yoshida, Y.: Long-term vicarious calibration of GOSAT shortwave sensors: Techniques for error reduction and new estimates of radiometric degradation factors, IEEE T. Geosci. Remote, 52, 3991-4004, 2014.

Lindqvist, H., O’Dell, C., Schuh, A., Baker, D., Cheeseman, M., Baker, I., Haynes, K., and Denning, S.: The potential of GOSAT $\mathrm{XCO}_{2}$ to evaluate land surface models, in preparation, 2015.

Liu, J., Bowman, K. W., Lee, M., Henze, D. K., Bousserez, N., Brix, H., Collatz, G. J., Menemenlis, D., Ott, L., Pawson, S., Jones, D., and Nassar, R.: Carbon monitoring system flux estimation and attribution: impact of ACOS-GOSAT $\mathrm{XCO}_{2}$ sampling on the inference of terrestrial biospheric sources and sinks, Tellus B, 66, 22486, doi:10.3402/tellusb.v66.22486, 2014.

Maksyutov, S., Takagi, H., Valsala, V. K., Saito, M., Oda, T., Saeki, T., Belikov, D. A., Saito, R., Ito, A., Yoshida, Y., Morino, I., Uchino, O., Andres, R. J., and Yokota, T.: Regional $\mathrm{CO}_{2}$ flux estimates for 2009-2010 based on GOSAT and groundbased $\mathrm{CO}_{2}$ observations, Atmos. Chem. Phys., 13, 9351-9373, doi:10.5194/acp-13-9351-2013, 2013.

Messerschmidt, J., Geibel, M. C., Blumenstock, T., Chen, H., Deutscher, N. M., Engel, A., Feist, D. G., Gerbig, C., Gisi, M., Hase, F., Katrynski, K., Kolle, O., Lavric, J. V., Notholt, J., Palm, M., Ramonet, M., Rettinger, M., Schmidt, M., Sussmann, R., Toon, G. C., Truong, F., Warneke, T., Wennberg, P. O., Wunch, D., and Xueref-Remy, I.: Calibration of TCCON column-averaged $\mathrm{CO}_{2}$ : the first aircraft campaign over European TCCON sites, Atmos. Chem. Phys., 11, 10765-10777, doi:10.5194/acp-11-10765-2011, 2011.

Messerschmidt, J., Chen, H., Deutscher, N. M., Gerbig, C., Grupe, P., Katrynski, K., Koch, F.-T., Lavric, J. V., Notholt, J., Rödenbeck, C., Ruhe, W., Warneke, T., and Weinzierl, C.: Automated ground-based remote sensing measurements of greenhouse gases at the Bialystok site in comparison with collocated in situ measurements and model data, Atmos. Chem. Phys., 12, 6741-6755, doi:10.5194/acp-12-6741-2012, 2012.

Morino, I., Uchino, O., Inoue, M., Yoshida, Y., Yokota, T., Wennberg, P. O., Toon, G. C., Wunch, D., Roehl, C. M., Notholt, J., Warneke, T., Messerschmidt, J., Griffith, D. W. T., Deutscher, N. M., Sherlock, V., Connor, B., Robinson, J., Sussmann, R., and Rettinger, M.: Preliminary validation of column-averaged volume mixing ratios of carbon dioxide and methane retrieved from GOSAT short-wavelength infrared spectra, Atmos. Meas. Tech., 4, 1061-1076, doi:10.5194/amt-4-1061-2011, 2011.

Morino, I., Matsuzaki, T., Ikegami, H., and Shishime, A.: TCCON data from Tsukuba, Ibaraki, Japan, 125HR, Release GGG2014R0, TCCON data archive, hosted by the Carbon Dioxide Information Analysis Center, Oak Ridge National Laboratory, Oak Ridge, Tennessee, USA, doi:10.14291/tccon.ggg2014.tsukuba02.R0/1149301, 2014.

Nakazawa, T., Murayama, S., Miyashita, K., Aoki, S., and Tanaka, M.: Longitudinally different variations of lower tropospheric carbon dioxide concentrations over the North Pacific Ocean, Tellus B, 44, 161-172, 1992. 
Nguyen, H., Osterman, G., Wunch, D., O’Dell, C., Mandrake, L., Wennberg, P., Fisher, B., and Castano, R.: A method for colocating satellite $\mathrm{XCO}_{2}$ data to ground-based data and its application to ACOS-GOSAT and TCCON, Atmos. Meas. Tech., 7, 26312644, doi:10.5194/amt-7-2631-2014, 2014.

Notholt, J., Petri, C., Warneke, T., Deutscher, N., Buschmann, M., Weinzierl, C., Macatangay, R., and Grupe, P.: TCCON data from Bremen, Germany, Release GGG2014R0, TCCON data archive, hosted by the Carbon Dioxide Information Analysis Center, Oak Ridge National Laboratory, Oak Ridge, Tennessee, USA, doi:10.14291/tccon.ggg2014.bremen01.R0/1149275, 2014.

O’Dell, C. W., Connor, B., Bösch, H., O’Brien, D., Frankenberg, C., Castano, R., Christi, M., Eldering, D., Fisher, B., Gunson, M., McDuffie, J., Miller, C. E., Natraj, V., Oyafuso, F., Polonsky, I., Smyth, M., Taylor, T., Toon, G. C., Wennberg, P. O., and Wunch, D.: The ACOS $\mathrm{CO}_{2}$ retrieval algorithm - Part 1: Description and validation against synthetic observations, Atmos. Meas. Tech., 5, 99-121, doi:10.5194/amt-5-99-2012, 2012.

Ohyama, H., Morino, I., Nagahama, T., Machida, T., Suto, H., Oguma, H., Sawa, Y., Matsueda, H., Sugimoto, N., Nakane, H., and Nakagawa, K.: Column-averaged volume mixing ratio of $\mathrm{CO}_{2}$ measured with ground-based Fourier transform spectrometer at Tsukuba, J. Geophys. Res., 114, D18303, doi:10.1029/2008JD011465, 2009.

Olsen, S. C. and Randerson, J. T.: Differences between surface and column atmospheric $\mathrm{CO}_{2}$ and implications for carbon cycle research, J. Geophys. Res., 109, D02301, doi:10.1029/2003JD003968, 2004.

Oshchepkov, S., Bril, A., Yokota, T., Wennberg, P. O., Deutscher, N. M., Wunch, D., Toon, G. C., Yoshida, Y., O'Dell, C. W., Crisp, D., Miller, C. E., Frankenberg, C., Butz, A., Aben, I., Guerlet, S., Hasekamp, O., Boesch, H., Cogan, A., Parker, R., Griffith, D., Macatangay, R., Notholt, J., Sussmann, R., Rettinger, M., Sherlock, V., Robinson, J., Kyrö, E., Heikkinen, P., Feist, D. G., Morino, I., Kadygrov, N., Belikov, D., Maksuytov, S., Matsunaga, T., Uchino, O., and Watanabe, H.: Effects of atmospheric light scattering on spectroscopic observations of greenhouse gases from space. Part 2: Algorithm intercomparison in the GOSAT data processing for $\mathrm{CO}_{2}$ retrievals over TCCON sites, J. Geophys. Res.-Atmos., 118, 1493-1512, doi:10.1002/jgrd.50146, 2013a.

Oshchepkov, S., Bril, A., Yokota, T., Yoshida, Y., Blumenstock, T., Deutscher, N. M., Dohe, S., Macatangay, R., Morino, I., Notholt, J., Rettinger, M., Petri, C., Schneider, M., Sussman, R., Uchino, O., Velazco, V., Wunch, D., and Belikov, D.: Simultaneous retrieval of atmospheric $\mathrm{CO}_{2}$ and light path modification from space-based spectroscopic observations of greenhouse gases: Methodology and application to GOSAT measurements over TCCON sites, Appl. Optics, 52, 1339-1350, 2013b.

Palmer, P. I., Barkley, M. P., and Monks, P. S.: Interpreting the variability of space-borne $\mathrm{CO}_{2}$ column-averaged volume mixing ratios over North America using a chemistry transport model, Atmos. Chem. Phys., 8, 5855-5868, doi:10.5194/acp-8-5855-2008, 2008.

Peng, S., Ciais, P., Chevallier, F., Peylin, P., Cadule, P., Sitch, S., Piao, S., Ahlström, A., Huntingford, C., Levy, P., Li, X., Liu, Y., Lomas, M., Poulter, B., Viovy, N., Wang, T., Wang, X., Zaehle, S., Zeng, N., Zhao, F., and Zhao, H.: Benchmarking the seasonal cycle of $\mathrm{CO}_{2}$ fluxes simulated by terres- trial ecosystem models, Global Biogeochem. Cy., 29, 46-64, doi:10.1002/2014GB004931, 2015.

Peters, W., Jacobson, A. R., Sweeney, C., Andrews, A. E., Conway, T. J., Masarie, K., Miller, J. B., Bruhwiler, L. M. P., Petron, G., Hirsch, A. I., Worthy, D. E. J., van der Werf, G. R., Randerson, J. T., Wennberg, P. O., Krol, M. C., and Tans, P. P.: An atmospheric perspective on North American carbon dioxide exchange: CarbonTracker, P. Natl. Acad. Sci., 104, 18925-18930, 2007.

Pitman, A. J.: The evolution of, and revolution in, land surface schemes designed for climate models, Int. J. Climatol., 23, 479510, doi:10.1002/joc.893, 2003.

Rayner, P. J. and O'Brien, D. M.: The utility of remotely sensed $\mathrm{CO}_{2}$ concentration data in surface source inversions, Geophys. Res. Lett., 28, 175-178, 2001.

Reuter, M., Bösch, H., Bovensmann, H., Bril, A., Buchwitz, M., Butz, A., Burrows, J. P., O’Dell, C. W., Guerlet, S., Hasekamp, O., Heymann, J., Kikuchi, N., Oshchepkov, S., Parker, R., Pfeifer, S., Schneising, O., Yokota, T., and Yoshida, Y.: A joint effort to deliver satellite retrieved atmospheric $\mathrm{CO}_{2}$ concentrations for surface flux inversions: the ensemble median algorithm EMMA, Atmos. Chem. Phys., 13, 1771-1780, doi:10.5194/acp-13-17712013, 2013.

Rodgers, C. D. and Connor, B. J.: Intercomparison of remote sounding instruments, J. Geophys. Res., 108, 4116, doi:10.1029/2002JD002299, 2003.

Sherlock, V., Connor, B., Robinson, J., Shiona, H., Smale, D., and Pollard, D.: TCCON data from Lauder, New Zealand, 125HR, Release GGG2014R0. TCCON data archive, hosted by the Carbon Dioxide Information Analysis Center, Oak Ridge National Laboratory, Oak Ridge, Tennessee, USA, doi:10.14291/tccon.ggg2014.lauder02.R0/1149298, 2014.

Sussmann, R. and Rettinger, M.: TCCON data from Garmisch, Germany, Release GGG2014R0, TCCON data archive, hosted by the Carbon Dioxide Information Analysis Center, Oak Ridge National Laboratory, Oak Ridge, Tennessee, USA, doi:10.14291/tccon.ggg2014.garmisch01.R0/1149299, 2014.

Takagi, H., Sacki, T., Oda, T., Saito, M., Valsala, V., Belikov, D., Saito, R., Yoshida, Y., Morino, I., Uchino, O., Andres, R. J., Yokota, T., and Maksuytov, S.: On the benefit of GOSAT observations to the estimation of regional $\mathrm{CO}_{2}$ fluxes, SOLA, 7, 161-164, doi:10.2151/sola.2011-041, 2011.

Takagi, H., Houweling, S., Andres, R. J., Belikov, D., Bril, A., Bösch, H., Butz, A., Guerlet, S., Hasekamp, O., Maksyutov, S., Morino, I., Oda, T., O’Dell, C. W., Oshchepkov, S., Parker, R., Saito, M., Uchino, O., Yokota, T., Yoshida, Y., and Valsala, $\mathrm{V}$.: Influence of differences in current GOSAT $\mathrm{XCO}_{2}$ retrievals on surface flux estimation, Geophys. Res. Lett., 41, 2598-2605, doi:10.1002/2013GL059174, 2014.

Taylor, T. E., O’Dell, C. W., O’Brien, D. M., Kikuchi, N., Yokota, T., Nakajima, T. Y., Ishida, H., Crisp, D., and Nakajima, T.: Comparison of cloud-screening methods applied to GOSAT near-infrared spectra, IEEE T. Geosci. Remote, 50, 295-309, doi:10.1109/TGRS.2011.2160270, 2012.

Warneke, T., Messerschmidt, J., Notholt, J., Weinzierl, C., Deutscher, N., Petri, C., Grupe, P., Vuillemin, C., Truong, F., Schmidt, M., Ramonet, M., and Parmentier, E.: TCCON data from Orleans, France, Release GGG2014R0. TCCON data archive, hosted by the Carbon Dioxide Information Analysis Center, Oak Ridge National Laboratory, Oak Ridge, Tennessee, 
USA， doi:10.14291/tccon.ggg2014.orleans01.R0/1149276, 2014.

Washenfelder, R. A., Toon, G. C., Blavier, J.-F. L., Yang, Z., Allen, N. T., Wennberg, P. O., Vay, S. A., Matross, D. M., and Daube, B. C.: Carbon dioxide column abundances at the Wisconsin Tall Tower site, J. Geophys. Res., 111, 1-11, doi:10.1029/2006JD007154, 2006.

Wennberg, P. O., Roehl, C., Blavier, J.-F., Wunch, D., Landeros, J., and Allen, N.: TCCON data from Jet Propulsion Laboratory, Pasadena, California, USA, Release GGG2014R0, TCCON data archive, hosted by the Carbon Dioxide Information Analysis Center, Oak Ridge National Laboratory, Oak Ridge, Tennessee, USA, doi:10.14291/tccon.ggg2014.jp102.R0/1149297, 2014a.

Wennberg, P. O., Roehl, C., Wunch, D., Toon, G. C., Blavier, J.-F., Washenfelder, R., Keppel-Aleks, G., Allen, N., and Ayers, J.: TCCON data from Park Falls, Wisconsin, USA, Release GGG2014R0, TCCON data archive, hosted by the Carbon Dioxide Information Analysis Center, Oak Ridge National Laboratory, Oak Ridge, Tennessee, USA, doi:10.14291/tccon.ggg2014.parkfalls01.R0/1149161, 2014b.

Wennberg, P. O., Wunch, D., Roehl, C., Blavier, J.-F., Toon, G. C., Allen, N., Dowell, P., Teske, K., Martin, C., and Martin, J.: TCCON data from Lamont, Oklahoma, USA, Release GGG2014R0, TCCON data archive, hosted by the Carbon Dioxide Information Analysis Center, Oak Ridge National Laboratory, Oak Ridge, Tennessee, USA, doi:10.14291/tccon.ggg2014.lamont01.R0/1149159, 2014c.

Wunch, D., Toon, G. C., Wennberg, P. O., Wofsy, S. C., Stephens, B. B., Fischer, M. L., Uchino, O., Abshire, J. B., Bernath, P., Biraud, S. C., Blavier, J.-F. L., Boone, C., Bowman, K. P., Browell, E. V., Campos, T., Connor, B. J., Daube, B. C., Deutscher, N. M., Diao, M., Elkins, J. W., Gerbig, C., Gottlieb, E., Griffith, D. W. T., Hurst, D. F., Jiménez, R., Keppel-Aleks, G., Kort, E. A., Macatangay, R., Machida, T., Matsueda, H., Moore, F., Morino, I., Park, S., Robinson, J., Roehl, C. M., Sawa, Y., Sherlock, V., Sweeney, C., Tanaka, T., and Zondlo, M. A.: Calibration of the Total Carbon Column Observing Network using aircraft profile data, Atmos. Meas. Tech., 3, 1351-1362, doi:10.5194/amt3-1351-2010, 2010.
Wunch, D., Toon, G. C., Blavier, J. F. L., Washenfelder, R. A., Notholt, J., Connor, B. J., Griffith, D. W. T., Sherlock, V., and Wennberg, P. O.: The total carbon column observing network, Philosophical Transactions of the Royal Society A: Mathematical, Phys. Eng. Sci., 369, 2087-2112, doi:10.1098/rsta.2010.0240, 2011a.

Wunch, D., Wennberg, P. O., Toon, G. C., Connor, B. J., Fisher, B., Osterman, G. B., Frankenberg, C., Mandrake, L., O’Dell, C., Ahonen, P., Biraud, S. C., Castano, R., Cressie, N., Crisp, D., Deutscher, N. M., Eldering, A., Fisher, M. L., Griffith, D. W. T., Gunson, M., Heikkinen, P., Keppel-Aleks, G., Kyrö, E., Lindenmaier, R., Macatangay, R., Mendonca, J., Messerschmidt, J., Miller, C. E., Morino, I., Notholt, J., Oyafuso, F. A., Rettinger, M., Robinson, J., Roehl, C. M., Salawitch, R. J., Sherlock, V., Strong, K., Sussmann, R., Tanaka, T., Thompson, D. R., Uchino, O., Warneke, T., and Wofsy, S. C.: A method for evaluating bias in global measurements of $\mathrm{CO}_{2}$ total columns from space, Atmos. Chem. Phys., 11, 12317-12337, doi:10.5194/acp11-12317-2011, 2011b.

Wunch, D., Wennberg, P. O., Messerschmidt, J., Parazoo, N. C., Toon, G. C., Deutscher, N. M., Keppel-Aleks, G., Roehl, C. M., Randerson, J. T., Warneke, T., and Notholt, J.: The covariation of Northern Hemisphere summertime $\mathrm{CO}_{2}$ with surface temperature in boreal regions, Atmos. Chem. Phys., 13, 9447-9459, doi:10.5194/acp-13-9447-2013, 2013.

Yokota, T., Yoshida, Y., Eguchi, N., Ota, Y., Tanaka, T., Watanabe, H., and Maksuytov, S.: Global concentrations of $\mathrm{CO}_{2}$ and $\mathrm{CH}_{4}$ retrieved from GOSAT: first preliminary results, SOLA, 5, 160163, 2009.

Yoshida, Y., Kikuchi, N., Morino, I., Uchino, O., Oshchepkov, S., Bril, A., Saeki, T., Schutgens, N., Toon, G. C., Wunch, D., Roehl, C. M., Wennberg, P. O., Griffith, D. W. T., Deutscher, N. M., Warneke, T., Notholt, J., Robinson, J., Sherlock, V., Connor, B., Rettinger, M., Sussmann, R., Ahonen, P., Heikkinen, P., Kyrö, E., Mendonca, J., Strong, K., Hase, F., Dohe, S., and Yokota, T.: Improvement of the retrieval algorithm for GOSAT SWIR $\mathrm{XCO}_{2}$ and $\mathrm{XCH}_{4}$ and their validation using TCCON data, Atmos. Meas. Tech., 6, 1533-1547, doi:10.5194/amt-6-1533-2013, 2013. 